\title{
Polyphenolic Profile of Callistemon viminalis Aerial Parts: Antioxidant, Anticancer and In Silico 5-LOX Inhibitory Evaluations
}

\author{
Shahenda Mahgoub ${ }^{1, *}$, Nashwa Hashad ${ }^{2}$, Sahar Ali ${ }^{1}$, Reham Ibrahim ${ }^{2}$, Ahmed M. Said ${ }^{3,4, *}$, \\ Fatma A. Moharram ${ }^{2, *}$ and Mohamed Mady ${ }^{2}$ (D)
}

1 Biochemistry and Molecular Biology Department, Faculty of Pharmacy, Helwan University, Ein-Helwan, Helwan, Cairo 11795, Egypt; ganah_nour@yahoo.com

2 Department of Pharmacognosy, Faculty of Pharmacy, Helwan University, Ein Helwan, Cairo 11795, Egypt; alsayednashwa@gmail.com (N.H.); reham_bassyoni@pharm.helwan.edu.eg (R.I.); mohamedsaid_1985@pharm.helwan.edu.eg (M.M.)

3 Department of Pharmaceutical Organic Chemistry, Faculty of Pharmacy, Helwan University, Ein-Helwan, Helwan, Cairo 11795, Egypt

4 Department of Chemistry, University at Buffalo, The State University of New York, Buffalo, NY 14260, USA

* Correspondence: Shahenda.mahgoub@pharm.helwan.edu.eg (S.M.); ahmedmoh@buffalo.edu (A.M.S.); Fatma_moharam@pharm.Helwan.edu.eg (F.A.M.); Tel.: +1716-907-5016 (A.M.S.); +202-2554-160 (F.A.M.)

check for updates

Citation: Mahgoub, S.; Hashad, N.; Ali, S.; Ibrahim, R.; Said, A.M.;

Moharram, F.A.; Mady, M.

Polyphenolic Profile of Callistemon viminalis Aerial Parts: Antioxidant, Anticancer and In Silico 5-LOX Inhibitory Evaluations. Molecules 2021, 26, 2481. https://doi.org/ $10.3390 /$ molecules26092481

Academic Editor: Teobald Kupka

Received: 2 April 2021

Accepted: 20 April 2021

Published: 24 April 2021

Publisher's Note: MDPI stays neutral with regard to jurisdictional claims in published maps and institutional affiliations.

Copyright: (c) 2021 by the authors. Licensee MDPI, Basel, Switzerland. This article is an open access article distributed under the terms and conditions of the Creative Commons Attribution (CC BY) license (https:// creativecommons.org/licenses/by/ $4.0 /)$.
Abstract: Five new compounds viz kaempferol 3-O-(4"'-galloyl)- $\beta$-D-glucopyranosyl-( $\left(1^{\prime \prime \prime} \rightarrow 6^{\prime \prime}\right)-O-$ $\beta$-D-glucopyranoside (1), kaempferol 3-O- $\beta$-D-mann-uronopyranoside (2), kaempferol 3-O- $\beta$-Dmannopyranoside (3), quercetin 3-O- $\beta$-D-mannuronopyranoside (4), 2, 3 (S)- hexahydroxydiphenoyl]D-glucose (5) along with fifteen known compounds were isolated from $80 \%$ aqueous methanol extract (AME) of C. viminalis. AME and compounds exerted similar or better antioxidant activity to ascorbic acid using $\mathrm{DPPH}, \mathrm{O}_{2}{ }^{-}$, and $\mathrm{NO}$ inhibition methods. In addition, compounds 16, 4, and 7 showed cytotoxic activity against MCF-7 cell lines while 3, 7 and 16 exhibited strong activity against HepG2. An in silico analysis using molecular docking for polyphenolic compounds 2, 3, 7, 16 and 17 against human stable 5-LOX was performed and compared to that of ascorbic acid and quercetin. The binding mode as well as the enzyme-inhibitor interactions were evaluated. All compounds occupied the 5-LOX active site and showed binding affinity greater than ascorbic acid or quercetin. The data herein suggest that AME, a source of polyphenols, could be used against oxidative-stress-related disorders.

Keywords: antioxidant; cytotoxicity; C. viminalis; flavonoids; polyphenolic; 5-LOX; molecular modelling

\section{Introduction}

Genus Callistemon (commonly known as bottlebrushes) belongs to the family Myrtaceae and comprises about 34 species, it is widely distributed across the world [1]. Callistemon viminalis (weeping bottlebrush) is found as a small tree or shrub distributed around the world particularly in tropical Asia, Australia, Sri Lanka, South America, and India [2] as well as cultivated in Egypt. It was planted as an ornamental plant, and as a source of essential oil [3]. C. viminalis is traditionally used for treating skin infections, hemorrhoids, gastroenteritis, diarrhea, and respiratory conditions [1,4]. Among the plant components, secondary metabolites like, phenolic compounds are of exceptional interest due to their noticeable health-related properties. From the chemical point of view, there are few reports about the phenolic compounds of $C$. viminalis which concentrated on the presence of flavonoids [5,6], tannins [6], and phenolic acid [3,6,7]. In addition, several phloroglucinol compounds were identified [8-10]. Moreover, some studies have demonstrated that the alcoholic extracts of the leaves, aerial parts, flower, bark, and fruits of $C$. viminalis possessed 
different biological activities as cytotoxic [5,11,12], antioxidant [6,7,11-15], hepatoprotective [6], antidiabetic [16], and analgesic activities [17]. Reactive oxygen species (ROS) are generated by different physiological processes and they have important functions in organisms; one of them is the defense function, as shown in the activation polymorphonuclear neutrophils by exogenous or endogenous motivations, which is followed by increasing the oxygen consumption and ROS production cascade leading to generation of other free radicals as superoxide anion $\left(\mathrm{O}_{2}{ }^{-}\right)$and hydrogen peroxide $\left(\mathrm{H}_{2} \mathrm{O}_{2}\right)$ [18]. ROS generation reactions can be elevated under certain conditions resulting in oxidative stress and tissues damage [19].

Though the NADPH oxidase family is well known as a main source of non-mitochondrial ROS in several cells, arachidonic acid (AA) metabolism by lipoxygenases (LOX) also plays a part in the generation of ROS in a variety of cells [20]. Lipoxygenases, nonheme ironcontaining enzymes, catalyze the peroxidation/oxidation of the lipids (polysaturated fatty acids) to form various reactive inflammatory mediators. These enzymes were found to significantly contribute to the pathogenesis of various diseases including cancers [21]. One important enzyme from the lipoxygenase family is 5-lipoxygenase (5-LOX) was found to trigger the inflammatory response through the biosynthesis of leukotrienes (LTs) [22]. During this process ROS are also formed as by-products [23]. Recent studies revealed that the overexpression of 5-LOX significantly contributes to certain autoimmune diseases, i.e., rheumatoid arthritis as well as severe allergic reactions, i.e., asthma [24]. In addition, several clinical and preclinical studies found out that the overexpression of 5-LOX was found to also significantly result in carcinogenesis [25]. Recent studies revealed that 5-LOX plays an important role in tumor formation through stimulating cell proliferation [26], apoptosis inhibition [27], excessive production of various mutagens [28]. 5-LOX was found to have a profound effect on the prognosis of several types of cancer, i.e., breast [25,29], colon, liver [30], and pancreatic cancer [31]. The inhibition of 5-LOX could be a potential therapeutic pathway to treat and prevent cancer formation via blocking the oxidative and inflammatory pathways [32].

Antioxidants from natural sources have been receiving great attention from consumers and researchers due to their several pharmacological activities as well as their ability to protect the organism from oxidative stresses caused by ROS [33]. Polyphenolic compounds are gaining significance due to their contribution to human health along with their several biological activities as antioxidant, antimutagenic, anticarcinogenic, and cytoprotective activities [34]. Considering ROS participation in several pathologic processes and the different use of natural polyphenols as therapeutics, this study was conducted to assess the polyphenolic profile of $80 \%$ aqueous methanol extract (AME) of C. viminalis aerial parts for ROS scavenging agents and evaluate if through their antioxidant properties, the extract and the pure isolated compounds can protect cells against oxidative stress. In addition, anticancer activity of AME along with isolated compounds against MCF-7 and HepG2 cancer cell lines were investigated. In addition, using molecular docking an in silico analysis for the binding mode and affinity of six polyphenolic compounds was performed and was compared to that of ascorbic acid and quercetin as reference drugs.

\section{Results and Discussion}

\subsection{Chemical Structure Elucidation of Compounds Isolated from C. viminalis Aerial Parts}

Fractionation of the AME of $C$. viminalis aerial parts on polyamide column followed by purification of the compounds on successive cellulose and Sephadex LH-20 columns resulted in isolation of five new compounds viz kaempferol 3-O-(4"-galloyl)- $\beta$ D-glucopyranosyl-( $\left.1^{\prime \prime \prime} \rightarrow 6^{\prime \prime}\right)$-O- $\beta$-D-glucopyranoside (1), kaempferol 3-O- $\beta$-D-mannuronopyranoside (2); kaempferol 3-O- $\beta$-D-mannopyranoside (3), quercetin 3-O- $\beta$-D-mannuronpyranoside (4) 2, 3 (S)-hexahydroxydiphenoyl]-D-glucose (5), together with four known kaempferol glycoside: kaempferol 7-methyl ether 3-O- $\beta$-D-glucopyranoside (9), kaempferol $4^{\prime}$ methyl ether 3-O- $\beta$-D-glucopyranoside (10), kaempferol 3-O- $\beta$-D-glucuronopyranoside (13) kaempferol 3-O- $\beta$-D-rhamnopyranoside (14) [35-37], four quercetin glycoside viz 
quercetin 3-O- $\beta$-D-xylopyranosyl-( $\left.1^{\prime \prime \prime} \rightarrow 2^{\prime \prime}\right)-O-\beta$-D-glucopyranoside $(7)[38,39]$, isoquercetin (15), quercitrin (16), quercetin 7-O- $\beta$-D-glucopyranoside (17) [35-37], five phenolic acid viz chlorogenic acid (6) [40], ellagic acid (8) [41], gallic (11), methyl gallate (12) [42], caffeic acid [40], (18) as well as two aglycones, kaempferol (19) and quercetin (20) [36]. All compounds were isolated from $C$. viminalis aerial parts for the first time except $(\mathbf{8}, \mathbf{1 1}-\mathbf{1 2}, \mathbf{1 5}-\mathbf{1 6}$, and 20). The structure of all compounds (Figure 1) was established using chemical and physical methods as 1-D and 2-D ${ }^{1}$ HNMR data as well as -ve HRESI MS data, in addition to comparison with authentic samples and previously reported data except for compounds $(6,8,11,12,14,18-20)$, which were identified with -ve HRESI MS and comparison with authentic samples.

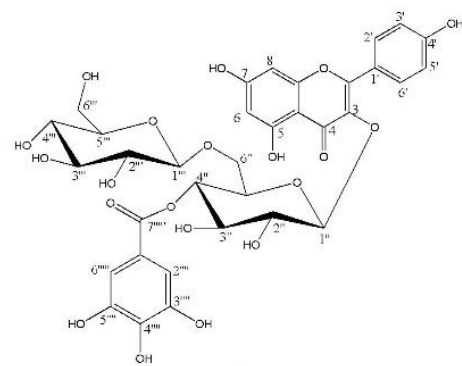

(1)<smiles>[R6]Oc1ccc(-c2oc3cc(OC)cc(O)c3c(=O)c2O)cc1</smiles>

2; $\mathrm{R}_{1}=\operatorname{ManA}, \mathrm{R}_{2}=\mathrm{H}, \mathrm{R}_{3}=\mathrm{H}$ 3; $\mathrm{R}_{1}=$ Man, $\mathrm{R}_{2}=\mathrm{H}, \mathrm{R}_{3}=\mathrm{H}$

9; $\mathrm{R}_{1}=\mathrm{Glc}, \mathrm{R}_{2}=\mathrm{CH}_{3}, \mathrm{R}_{3}=\mathrm{H}$

10; $\mathrm{R}_{1}=\mathrm{Glc}, \mathrm{R}_{2}=\mathrm{H}, \mathrm{R}_{3}=\mathrm{CH}_{3}$

13, $\mathrm{R}_{1}=\mathrm{GlcA}, \mathrm{R}_{2}=\mathrm{H}, \mathrm{R}_{3}=\mathrm{H}$

14, $\mathrm{R}_{1}=\mathrm{Rha}, \mathrm{R}_{2}=\mathrm{H}, \mathrm{R}_{3}=\mathrm{H}$

19; $\mathrm{R}_{1}=\mathrm{H}, \mathrm{R}_{2}=\mathrm{H}, \mathrm{R}_{3}=\mathrm{H}$

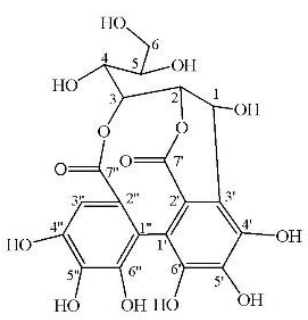

(5)

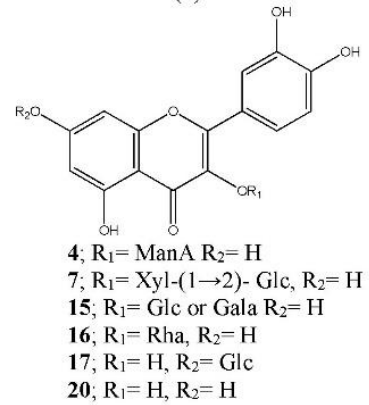<smiles>O=C(/C=C/c1ccc(O)c(O)c1)OC1CC(O)(C(=O)O)CC(O)C1O</smiles>

(6)

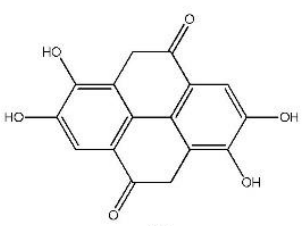

(8)

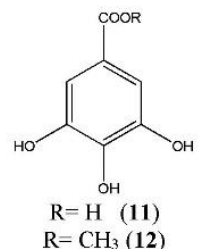

$\mathrm{R}=\mathrm{CH}_{3}(12)$<smiles>O=C(O)/C=C/c1ccc(O)c(O)c1</smiles>

(18)

Figure 1. Structures of polyphenolic compounds from C. viminalis aerial parts. Glc: Glucose, Gala: Galactose, GlcA: Glucuronic acid, Man: Mannose, ManA: Mannuronic acid, Rha: Rhamnose.

2.1.1. Kaempferol 3-O-( $4^{\prime \prime}$-galloyl)- $\beta$-D-glucopyranosyl-( $\left(1^{\prime \prime \prime} \rightarrow 6^{\prime \prime}\right)-O-\beta$-D-glucopyranoside (1)

Compound 1 was isolated as a yellow amorphous powder and gave dark purple color under UV light on PC which changed to yellowish-green and green color upon spraying with Naturstoff and $\mathrm{FeCl}_{3}$, respectively. Moreover, it gave kaempferol and gallic in the organic phase and glucose in the aqueous one upon acid hydrolysis and comparison with authentic sample on PC (COPC). Therefore, based on its chromatographic data and acid hydrolysis it was expected that 1 is related to kaempferol 3-O-glycoside [37]. ${ }^{1} \mathrm{H}$ NMR spectrum of 1 (Table 1) showed $\mathrm{A}_{2} \mathrm{X}_{2}$ spin coupling system of two ortho-doublets protons at $\delta_{\mathrm{H}}$ 8.07 and 6.86 for $\mathrm{H}-2^{\prime} / 6^{\prime}$ and $\mathrm{H}-3^{\prime} / 5^{\prime}$, respectively, together with an AM system of two metadoublets protons for $\delta_{\mathrm{H}} 6.44$ and 6.21 for $\mathrm{H}-8$ and $\mathrm{H}-6$, respectively, which are characteristic 
for kaempferol aglycone [34]. This finding is further confirmed by their ${ }^{13} \mathrm{CNMR}$ spectrum (Table 1) which displays fifteen carbon signals characteristic for kaempferol aglycone with the key signals at $\delta_{C} 177.8(C-4), 131.4\left(C-2^{\prime} / 6^{\prime}\right), 115.7\left(C-3^{\prime} / 5^{\prime}\right.$ and $160.3\left(C-4^{\prime}\right)$ [36]. Additionally, ${ }^{1} \mathrm{H}$ NMR data displayed a singlet signal integrated for two protons at $\delta_{\mathrm{H}}$ 6.97 characteristics for $\mathrm{H}-2^{\prime \prime \prime \prime} / 6^{\prime \prime \prime \prime}$ of galloyl moiety [43]. Moreover, the presence of two doublet signals in the aliphatic region at $\delta_{\mathrm{H}} 5.39$ and $5.46(\mathrm{~J}=8 \mathrm{~Hz})$ gave evidence for the presence of two anomeric protons ( $\mathrm{H}-\mathrm{1}^{\prime \prime}$ and $\left.\mathrm{H}-\mathrm{1}^{\prime \prime \prime}\right)$ characteristic for glucose moiety which agreed with the acid hydrolysis results. The presence of galloyl moiety was confirmed by ${ }^{13} \mathrm{C}$ NMR and HMBC data (Table 1, Figure 2), through the presence of seven carbons signals with the key signals among which $\delta_{\mathrm{C}} 165.7$ for the carbonyl carbon $\left(\mathrm{C}-7^{\prime \prime \prime \prime}\right)$ and $\delta_{C}$ at 145.8 and 109.2 for $C-3^{\prime \prime \prime \prime} / 5^{\prime \prime \prime \prime}$ and $C-2^{\prime \prime \prime \prime} / 6^{\prime \prime \prime \prime}$, respectively as well as the HMBC correlation between $\mathrm{H}-2^{\prime \prime \prime \prime} / 6^{\prime \prime \prime \prime}$ and C- $1^{\prime \prime \prime \prime}\left(\delta_{C} 119.5\right), C-4^{\prime \prime \prime \prime}\left(\delta_{C} 139.0\right), C-3^{\prime \prime \prime \prime} / 5^{\prime \prime \prime \prime}\left(\delta_{C}\right.$ $145.9 \mathrm{ppm})$ and $C-7^{\prime \prime \prime \prime}\left(\delta_{C} 165.7 \mathrm{ppm}\right)$. The two sugar moieties were established by the presence of twelve carbon signals, two of them are anomeric carbons at $\delta_{C} 102.1\left(\mathrm{C}-1^{\prime \prime}\right)$, and $101.2\left(C-1^{\prime \prime \prime}\right)$ and the remaining carbon signals were at the range between $\delta_{C} 77.7-60.8$, which indicated that the two-sugar moiety consisted of two $\beta$-D glucopyranosides [35,36]. The sugar moieties are attached to C-3 of the kaempferol aglycone due to the up-field shift of $C-3\left(\delta_{C} 133.8\right)$ and downfield shift of $C-2$ at $\delta_{C} 156.8$ [36], as well as the HMBC correlation between $\mathrm{H}-1^{\prime \prime}\left(\delta_{\mathrm{H}} 5.39\right)$ and $\mathrm{C}-3\left(\delta_{\mathrm{C}} 133.8\right)$. The inter glycosidic linkage between the two glucose units was $1^{\prime \prime \prime} \rightarrow 6^{\prime \prime}$ due to the downfield shift of $\mathrm{H}-6^{\prime \prime}$ in the ${ }^{1} \mathrm{H}$ NMR at $\delta_{\mathrm{H}} 3.66$, corresponding to the free one $\delta_{\mathrm{H}} 3.29\left(\mathrm{C}-6^{\prime \prime \prime}\right)$, in addition to the downfield shift of $C-6^{\prime \prime}$ at $\delta_{C} 68.2$ vs. C- $6^{\prime \prime \prime}\left(\delta_{C} 60.8\right)$. Additionally, the correlation between $\mathrm{H}-1^{\prime \prime \prime}\left(\delta_{\mathrm{H}} 5.46\right)$ and $C-6^{\prime \prime}\left(\delta_{C} 68.2\right)$ in the HMBC spectrum. The position of galloyl moiety was confirmed at $\mathrm{C}-4^{\prime \prime}$ due to the downfield shift of $\mathrm{H}-4^{\prime \prime}$ in the ${ }^{1} \mathrm{H}$ NMR spectrum at $\delta_{\mathrm{H}} 4.82$ as well as its downfield in the ${ }^{13} C$ NMR at $\delta_{C} 71.9$, in addition to the upfield shift of $C-3^{\prime \prime}\left(\delta_{C} 74.3\right)$ and $C-5^{\prime \prime}\left(\delta_{C} 71.6\right)$. Moreover, the correlation between $\mathrm{H}-4^{\prime \prime}\left(\delta_{\mathrm{H}} 4.82\right)$ and $\mathrm{C}-7^{\prime \prime \prime \prime}\left(\delta_{\mathrm{C}} 165.7\right), \mathrm{C}-$ $3^{\prime \prime}\left(\delta_{C} 74.3\right), C-5^{\prime \prime}\left(\delta_{C} 71.6\right)$ and $C-6^{\prime \prime}\left(\delta_{C} 68.2\right)$ in the HMBC. HMQC spectrum confirmed that all non-exchangeable proton resonances were associated with the directly attached carbon atoms. Therefore, compound $\mathbf{1}$ was identified as kaempferol 3-O-(4" -galloyl)- $\beta$-Dglucopyranosyl- $\left(1^{\prime \prime \prime} \rightarrow 6^{\prime \prime}\right)-O-\beta$-D-glucopyranoside, which was isolated for the first time from nature.

Table 1. ${ }^{1} \mathrm{H}(400 \mathrm{MHz})$ and ${ }^{13} \mathrm{C}-\mathrm{NMR}(100 \mathrm{MHz})$ in (DMSO) data for compound 1.

\begin{tabular}{|c|c|c|c|}
\hline Carbon No & $\delta_{C}$ & $\delta_{\mathrm{H}} *$ & H-MBC \\
\hline 2 & 156.8 & & \\
\hline 3 & 133.8 & & \\
\hline 4 & 177.8 & & \\
\hline 5 & 161.8 & & \\
\hline 6 & 98.9 & 6.21 (br s) & C-5, C-8, C-10 \\
\hline 7 & 164.6 & & \\
\hline 8 & 94.2 & 6.44 (br s) & C-6, C-7, C-9, C-10 \\
\hline 9 & 156.9 & & \\
\hline 10 & 104.4 & & \\
\hline $\mathbf{1}^{\prime}$ & 121.2 & & \\
\hline $2^{\prime} / 6^{\prime}$ & 131.4 & $8.07(\mathrm{~d}, 8 \mathrm{~Hz})$ & $C-2, C-4^{\prime}$ \\
\hline $4^{\prime}$ & 160.3 & & \\
\hline $3^{\prime} / 5^{\prime}$ & 115.7 & $6.86(\mathrm{~d}, 8)$ & $C-1^{\prime}, C-4^{\prime}$ \\
\hline $\mathrm{OH}-5$ & & 12.62 & \\
\hline $1^{\prime \prime}$ & 102.1 & $5.39(\mathrm{~d}, 8)$ & C-3 \\
\hline $2^{\prime \prime}$ & $74.2 \#$ & 3.52 & \\
\hline $3^{\prime \prime}$ & 74.3 & 3.14 & \\
\hline $4^{\prime \prime}$ & 71.9 & 4.82 & $\mathrm{C}-3^{\prime \prime}, \mathrm{C}-5^{\prime \prime}, \mathrm{C}-6^{\prime \prime}, \mathrm{C}-7^{\prime \prime \prime \prime}$ \\
\hline $5^{\prime \prime}$ & 71.6 & 3.53 & \\
\hline $6^{\prime \prime}$ & 68.2 & 3.66 & $C-1^{\prime \prime \prime}$ \\
\hline $1^{\prime \prime \prime}$ & 101.2 & $5.46(\mathrm{~d}, 8)$ & $C-6^{\prime \prime}$ \\
\hline
\end{tabular}


Table 1. Cont.

\begin{tabular}{|c|c|c|c|}
\hline Carbon No & $\delta_{C}$ & $\delta_{\mathrm{H}}{ }^{*}$ & H-MBC \\
\hline $2^{\prime \prime \prime}$ & 73.5 \# & 3.37 & \\
\hline $3^{\prime \prime \prime}$ & 77.7 & 3.08 & \\
\hline $4^{\prime \prime \prime}$ & 70.2 & 3.08 & \\
\hline $5^{\prime \prime \prime}$ & 76.1 & 3.33 & \\
\hline $6^{\prime \prime \prime}$ & 60.8 & $3.29,3.44$ & \\
\hline $\mathbf{1}^{\prime \prime \prime \prime}$ & 119.5 & & \\
\hline $2^{\prime \prime \prime \prime} / 6^{\prime \prime \prime \prime}$ & 109.2 & 6.97 (br s) & $C_{1^{\prime \prime \prime \prime \prime}}, C_{4^{\prime \prime \prime \prime \prime}}, C_{3^{\prime \prime \prime \prime \prime} / 5^{\prime \prime \prime \prime \prime \prime}}, C_{7^{\prime \prime \prime \prime \prime}}$ \\
\hline $3^{\prime \prime \prime \prime} / 5^{\prime \prime \prime \prime}$ & 145.8 & & \\
\hline $4^{\prime \prime \prime \prime \prime}$ & 139.0 & & \\
\hline $7^{\prime \prime \prime \prime}$ & 165.7 & & \\
\hline
\end{tabular}

Value between parentheses represent $\mathrm{J}$ value in $\mathrm{Hz} ;{ }^{*}$ Value of sugar proton obtained from HMQC \# Value may be interchangeable.

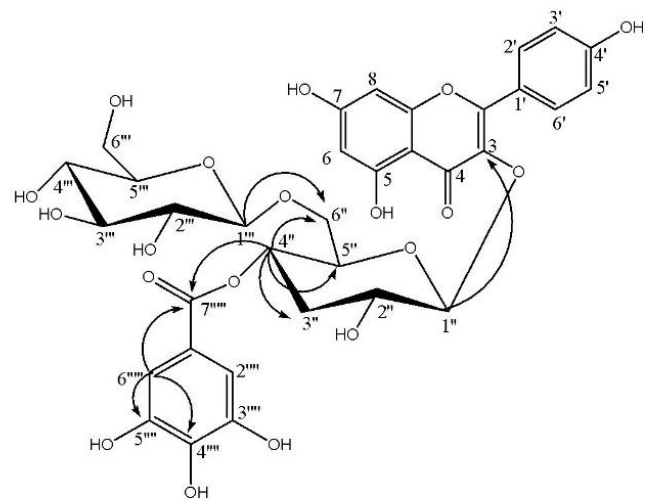

(1)

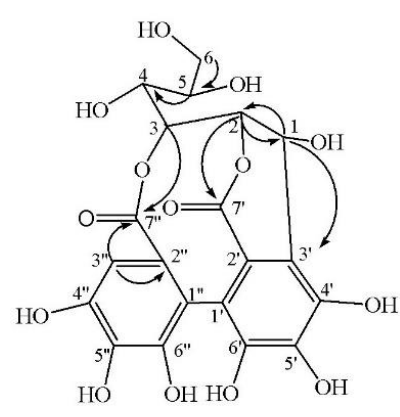

(5)

Figure 2. HMBC correlations of compound (1) and (5).

2.1.2. Kaempferol 3-O- $\beta$-D-mannuronopyranoside (2) and kaempferol 3-O- $\beta$-D-mannopyranoside (3)

Compounds 2 and 3 were isolated as yellow amorphous powders and they gave the chromatographic properties characteristic for kaempferol 3-O-glycoside as in 1 [37]. Additionally, they gave kaempferol as aglycone (organic phase) and mannuronic acid in case of $\mathbf{2}$ and mannose in $\mathbf{3}$ (aqueous phase) upon acid hydrolysis and comparison with authentic sample and spraying reagents on PC. Therefore, based on their chromatographic data and acid hydrolysis it was expected that 2 and 3 are related to kaempferol 3-Oglycoside [36,37]. ${ }^{1} \mathrm{H}$ and ${ }^{13} \mathrm{C}$ NMR spectrum of 2 and 3 (Table 2) displayed the proton and carbon signals characteristic for kaempferol aglycone as in $\mathbf{1}$. Concerning the sugar moiety, ${ }^{1} \mathrm{H}$ NMR of both compounds showed a doublet singlet at $\delta_{\mathrm{H}} \approx 5.4$ with small J-coupling $\left(\approx 2.4 \mathrm{~Hz}\right.$ ) for $\mathrm{H}-1^{\prime \prime}$ characteristic for mannuronic acid and mannose [44,45]. Moreover, from their ${ }^{13} \mathrm{C}$ NMR data, the presence of mannuronic acid in $\mathbf{2}$ was established due to the presence of $C-1^{\prime \prime}$ at $\delta_{C} 101.6$ and $C-6^{\prime \prime}$ at $\delta_{C} 171.5$, together with four carbon signals ranged between $\delta_{C} 76.4-74.3$, while mannose in case of 3 was confirmed by the presence of six carbon signals among which, $C-1^{\prime \prime}\left(\delta_{C}\right.$ 101.6) and $C-6^{\prime \prime}\left(\delta_{C} 62.3\right)$. Therefore, the sugar moiety was established as $\beta$-D-mannuronopyranoside and $\beta$-D-mannopyranoside, in case of 2 and 3, respectively [33], which agreed with the result of acid hydrolysis. The attachment of the sugar moieties was at C-3 of the aglycone, as in the case of $\mathbf{1}$ due to the upfield shift of $C-3$ at $\delta_{C} \approx 133.5$ and downfield shift of $C-2$ at $\delta_{C} 156.8$ [36]. Final confirmation of the compound 2 and 3 was established from their -ve HRESI-MS, which revealed the presence of a molecular ion peak at $m / z 461.1359[\mathrm{M}-\mathrm{H}]^{-}$and $447.0941[\mathrm{M}-\mathrm{H}]^{-}$for kaempferol 3- $\beta$-D-mannuronopyranoside (2) kaempferol 3-O- $\beta$-D-mannopyranoside (3), which were also isolated for the first time from nature. 
Table 2. ${ }^{1} \mathrm{H}(400 \mathrm{MHz})$ and ${ }^{13} \mathrm{C}-\mathrm{NMR}(100 \mathrm{MHz})$ in (DMSO) data for compound 2 and 3.

\begin{tabular}{|c|c|c|c|c|}
\hline \multirow{2}{*}{ Carbon No } & \multicolumn{2}{|c|}{2} & \multicolumn{2}{|c|}{3} \\
\hline & $\delta \mathrm{C}$ & $\delta \mathbf{H}$ & $\delta \mathrm{C}$ & $\delta \mathbf{H}$ \\
\hline \multicolumn{5}{|l|}{1} \\
\hline 2 & 156.8 & & 156.8 & \\
\hline 3 & 133.5 & & 133.9 & \\
\hline 4 & 177.5 & & 177.8 & \\
\hline 5 & 161.5 & & 161.5 & \multirow{3}{*}{6.14 (brs) } \\
\hline 6 & 99.4 & \multirow[t]{2}{*}{6.16 (brs) } & 97.5 & \\
\hline 7 & 164.9 & & 164.6 & \\
\hline 8 & 94.2 & \multirow[t]{4}{*}{ 6.38(brs) } & 94.4 & \multirow[t]{4}{*}{6.36 (brs) } \\
\hline 9 & 156.8 & & 156.8 & \\
\hline 10 & 104.1 & & 104.4 & \\
\hline $\mathbf{1}^{\prime}$ & 121.1 & & 121.4 & \\
\hline $2^{\prime} / 6^{\prime}$ & 131.7 & \multirow[t]{2}{*}{$8.03(\mathrm{~d}, 7.2)$} & 131.7 & \multirow[t]{2}{*}{$8.03(\mathrm{~d}, 6.8)$} \\
\hline $4^{\prime}$ & 160.6 & & 160.3 & \\
\hline $3^{\prime} / 5^{\prime}$ & 115.6 & $6.86(\mathrm{~d}, 7.2)$ & 115.7 & $6.86(\mathrm{~d}, 6.8)$ \\
\hline OH-5 & & 12.48 & & 12.49 \\
\hline $1^{\prime \prime}$ & 101.6 & $5.45(2.8)$ & 101.6 & $5.43(\mathrm{~d}, 2.4)$ \\
\hline $2^{\prime \prime}$ & 74.3 & \multirow{5}{*}{$4.14-3.25$} & 72.1 & \multirow{5}{*}{$3.51-3.24$} \\
\hline $3^{\prime \prime}$ & 75.6 & & 74.3 & \\
\hline $4^{\prime \prime}$ & 72.1 & & 70.2 & \\
\hline $5^{\prime \prime}$ & 76.4 & & 76.5 & \\
\hline $6^{\prime \prime}$ & 171.6 & & 62.4 & \\
\hline
\end{tabular}

Values between parentheses represent the $J$ values in $\mathrm{Hz}$.

\subsubsection{Quercetin 3-O- $\beta$-D-mannuronopyranoside (4)}

Compound $\mathbf{4}$ was isolated as an amorphous yellow powder, it appeared as a dark purple color under UV light, which was changed to orange and green color by spraying with Naturstoff and $\mathrm{FeCl}_{3}$, respectively. Therefore, based on these data, it was expected that 4 belonged to quercetin 3-O-glycoside [37]. Complete acid hydrolysis of 4 resulted in quercetin aglycone in the organic phase and mannuronic acid in the aqueous one (COPC). Further evidence for the structure of 4 resulted from ${ }^{1} \mathrm{H}$ NMR data which showed two aromatic spin coupling systems, one is ABX system at $\delta_{\mathrm{H}} 7.89,7.48$ and 6.84 for $\mathrm{H}-2^{\prime}, \mathrm{H}-6^{\prime}$ and $\mathrm{H}-5^{\prime}$, respectively and the other is AM system at $\delta_{\mathrm{H}} 6.40$ and 6.19 for $\mathrm{H}-8$ and $\mathrm{H}-6$, respectively supporting the presence of quercetin nucleus [37]. Moreover, the presence of doublet signal at $\delta_{\mathrm{H}} 5.35$ with small $J$ coupling $2.0 \mathrm{~Hz}$ in the aliphatic region gave evidence for the presence of mannose or mannuronic acid as a sugar moiety [44,45]. Moreover, ${ }^{13} \mathrm{C}$ NMR data displayed the fifteen carbon signals resonances characteristic for quercetin nucleus [36], in addition to six carbon signals characteristic for mannuronic acid among which $C-1{ }^{\prime \prime}\left(\delta_{C} 102.2\right)$ and $C-7^{\prime \prime}\left(\delta_{C} 171.9\right)$ [46]. Final confirmation of 4 was established from -ve HRESI-MS data, which showed molecular ion peak at $m / z 477.1472$ with fragment ion peak at 301.1082 [quercetin-H] ${ }^{-}$. Accordingly, 4 was identified as quercetin 3-O- $\beta$-Dmannuronopyranoside, which was isolated for the first time from nature.

\subsubsection{2,3 (S)-hexahydroxydiphenoyl-D-glucose (5)}

Compound 5 showed a dark purple-fluorescent spot under short UV-light, which turned to an indigo-red and deep blue color by spraying with $\mathrm{NaNO}_{2}$, glacial AcOH and $\mathrm{FeCl}_{3}$, respectively characteristic for hexahydroxy diphenoyl (HHDP) containing ellagitannin. Moreover, it did not give ellagic acid or glucose on complete acid hydrolysis, which is considered as strong evidence for the $C$-glycosidic structure of $5 .{ }^{1} \mathrm{H}$ NMR data (Table 3) displayed one singlet signal at $\delta_{\mathrm{H}} 6.16$ for $\mathrm{H}-3^{\prime \prime}$ of HHDP ester moieties with the loss of one proton $\left(\mathrm{H}-3^{\prime}\right)$, due to the oxidative coupling and formation of extra C-C linkage with the anomeric position of the sugar moiety. Furthermore, the $C$-glycosidic structure and open-chain glucose moiety in the structure was in turn established from the appearance of sugar protons in the range of $\delta_{\mathrm{H}} 5.43-3.34$. Additionally, the appearance of 
the anomeric protons as a doublet with a small $J$ value $(4.8 \mathrm{~Hz})$ at $\delta_{\mathrm{H}} 5.42$ was indicative of a $\beta$ specific absolute configuration at $\mathrm{C}-1$ with axial $\mathrm{OH}[47,48]$. The position of attachment of HHDP moiety at H-2 and H-3 was established from the downfield shift of H-2 and 3 at $\delta_{\mathrm{H}} 4.56$ and 5.06, respectively. Further confirmation of the structure was obtained from ${ }^{13} \mathrm{CNMR}$ which displayed the six carbons signal for glucose moiety in the range of 63.2- 76.5. The open-chain nature of glucose instead of hemiacetal ${ }^{4} C_{1}$-pyranose was established due to the strong up-field shift of C-1 at $\delta_{C} 66.9$, in comparison to that of pyranose $(\delta \approx 90-95$ ppm). Likewise, the $C$-glycosidic nature was further evidenced by the typical downfield shift of C-3' (HHDP) at $116.2(\approx+10)$ and up-field location of C-7' at $164.3(\approx-6)$ concerning those of $C-3^{\prime \prime}$ at 103.4 and $C-7^{\prime \prime}$ at 170.6 [34,35]. The assignment of the remaining carbon signal characteristic for open-chain sugar and HHDP moiety was compared with the reported data of C-glycosidic tannins [47-49]. HMQC spectrum confirmed that all non-exchangeable proton resonances were associated with the directly attached carbon atoms. Additional confirmation of the compound was established from HMBC (Table 3, Figure 2), which showed the correlation between H-1 $\left(\delta_{\mathrm{H}} 5.43\right)$ with C-3' $\left(\delta_{\mathrm{C}} 116.2\right)$ and $\mathrm{C}-2\left(\delta_{\mathrm{C}} 76.5\right)$, as well as the correlation between $\mathrm{H}-2\left(\delta_{\mathrm{H}} 4.56\right), \mathrm{C}-1\left(\delta_{\mathrm{C}} 66.9\right)$ and $C-7^{\prime}\left(\delta_{C} 164.3\right)$, which confirmed the C-C linkage of 5. Moreover, H-3 ${ }^{\prime \prime}\left(\delta_{\mathrm{H}} 6.16\right)$ was confirmed from the correlation with $C-2^{\prime \prime}, C-7^{\prime \prime}$. Final confirmation was established from the negative HRESI/MS, which displayed a molecular ion peak at $m / z 481.0970{\text { [M }-\mathrm{H}]^{-}}^{-}$ corresponding to a mono-hexahydroxydiphenoyl-glucose. Accordingly, Compound 5 was identified as 2,3 (S)-hexahydroxydiphenoyl-D-glucose, which was isolated from nature for the first time.

Table 3. ${ }^{1} \mathrm{H}(400 \mathrm{MHz})$ and ${ }^{13} \mathrm{C}-\mathrm{NMR}(100 \mathrm{MHz})$ in (DMSO) data for compound 5.

\begin{tabular}{|c|c|c|c|c|c|c|c|}
\hline $\begin{array}{c}\text { Carbon } \\
\text { No }\end{array}$ & $\delta_{C}$ & $\delta_{\mathbf{H}}$ & НМВС & $\begin{array}{c}\text { Carbon } \\
\text { No }\end{array}$ & $\delta_{C}$ & $\delta_{H}$ & НМВС \\
\hline 1 & 66.9 & $5.43(\mathrm{~d}, 4.8)$ & $C-2, C-3^{\prime}$ & $5^{\prime}$ & 137.9 & & \\
\hline 2 & 76.5 & $4.56(\mathrm{dd}, 2,4)$ & C-1, C-7' & $6^{\prime}$ & 145.9 & & \\
\hline 3 & 71.4 & $5.06(\mathrm{~m})$ & $C-7^{\prime \prime}$ & $7^{\prime}$ & 164.3 & & \\
\hline 4 & 71.1 & $3.36(\mathrm{~m})$ & & $1^{\prime \prime}$ & 115.7 & & \\
\hline 5 & 74.6 & $3.57(\mathrm{dd}, 3.2,1.6)$ & C-4 & $2^{\prime \prime}$ & 126.9 & & \\
\hline 6 & 63.2 & $3.34-3.44(\mathrm{~m})$ & $C-5$ & $3^{\prime \prime}$ & 103.4 & $6.16(\mathrm{~s})$ & $C-2^{\prime \prime}, C-7^{\prime \prime}$ \\
\hline $1^{\prime}$ & 115.8 & & & $4^{\prime \prime}$ & 144.3 & & \\
\hline $2^{\prime}$ & 119.9 & & & $5^{\prime \prime}$ & 133.9 & & \\
\hline $3^{\prime}$ & 116.2 & & & $6^{\prime \prime}$ & 145.3 & & \\
\hline $4^{\prime}$ & 143.0 & & & $7^{\prime \prime}$ & 170.6 & & \\
\hline
\end{tabular}

\subsection{Antioxidant Activity}

Erkan et al., 2008 [50], reported the close correlation between radical scavenging activity, total flavonoid, and phenolic content of various natural sources. The scavenging ability of DPPH free radical is commonly used for evaluation of the antioxidant activity of natural compounds. Moreover, there are several in vitro complementary assays that are used based on the inactivation of $\mathrm{NO}$ and $\mathrm{O}_{2}{ }^{-}$radicals [51]. In this study, different assays were used to evaluate the antioxidant potential of the extract and some pure compounds to establish the mechanism of action of them [52]. We noticed that AME and pure tested compounds 2-4, 7, 10, and 15-17 exhibited strong antioxidant activity through their ability to inhibit $\mathrm{DPPH}, \mathrm{NO}$, and $\mathrm{O}_{2}{ }^{-}$radicals (Table 4).

\subsubsection{DPPH Radical Scavenging Activity}

This assay is based on the ability of the stable DPPH radical to react with hydrogen donors including phenolics. We found that all compounds exerted higher DPPH scavenging activity than that of ascorbic acid $\left(\mathrm{IC}_{50}=111.3 \mu \mathrm{M}\right)$, with compounds 2, 3, 7 , and 17 being the most active compounds $\left(\mathrm{IC}_{50}=13.2,19.9,11.4\right.$ and $19.2 \mu \mathrm{M}$, respectively). While AME $\left(\mathrm{IC}_{50}=25.48 \mu \mathrm{g} / \mathrm{mL}\right)$ exhibited close activity to that of ascorbic acid $(19.63 \pm 0.37 \mu \mathrm{g} / \mathrm{mL})$. 
Table 4. Antioxidant activities of the AME of the C. viminalis and pure compounds.

\begin{tabular}{cccc}
\hline \multirow{2}{*}{ Compound/Extract } & \multicolumn{3}{c}{ IC $_{\mathbf{5 0}} \boldsymbol{\mu} \mathbf{g} / \mathbf{m L} \pm$ SEM (IC $\left.\mathbf{5 0} \boldsymbol{\mu M}\right)$} \\
\cline { 2 - 4 } & DPPH & NO & SOD \\
\hline AME & $25.48 \pm 0.29$ & $12.67 \pm 0.84$ & $0.50 \pm 0.29$ \\
$\mathbf{2}$ & $6.08 \pm 0.05(13.2)$ & $10.70 \pm 1.58(23.2)$ & $10.18 \pm 0.49(22.1)$ \\
$\mathbf{3}$ & $8.93 \pm 0.17(19.9)$ & $11.21 \pm 0.47(25)$ & $6.05 \pm 0.57(13.6)$ \\
$\mathbf{4}$ & $15.86 \pm 0.21(33.3)$ & $16.55 \pm 0.29(34.7)$ & $6.00 \pm 0.34(12.6)$ \\
$\mathbf{7}$ & $6.51 \pm 0.18(11.4)$ & $15.10 \pm 1.56(26.5)$ & $11.58 \pm 0.41(20.4)$ \\
$\mathbf{1 0}$ & $18.13 \pm 0.38(39.2)$ & $12.03 \pm 0.76(26.0)$ & $6.76 \pm 0.16(14.7)$ \\
$\mathbf{1 5}$ & $22.14 \pm 0.31(47.6)$ & $11.51 \pm 1.91(24.8)$ & $6.06 \pm 0.57(13.1)$ \\
$\mathbf{1 6}$ & $19.39 \pm 0.58(43.3)$ & $7.84 \pm 0.88(17.4)$ & $21.48 \pm 0.57(48)$ \\
$\mathbf{1 7}$ & $8.94 \pm 0.28(19.2)$ & $13.13 \pm 0.74(28.2)$ & $5.27 \pm 0.49(11.4)$ \\
Ascorbic acid & $19.63 \pm 0.37(111.3)$ & $12.95 \pm 0.77(73.5)$ & $21.62 \pm 0.40(122.6)$ \\
\hline
\end{tabular}

Data are displayed as mean \pm SEM of $\mathrm{IC}_{50}$ of three experiments. Value between () is $\mathrm{IC}_{50}$ in $\mu \mathrm{M}$.

\subsubsection{NO Radical Scavenging Activity}

Nitric oxide (NO) is a vital chemical mediator generated by neurons, macrophages, and endothelial cells. It is involved in the regulation of various physiological processes. However, excess generation of $\mathrm{NO}$ is associated with numerous diseases [53]. Under aerobic conditions, NO reacts with oxygen to produce nitrite. Scavengers of NO compete with oxygen leading to reduced production of nitrite ions. The results showed that all compounds showed activity more than that of ascorbic acid $\left(\mathrm{IC}_{50}=73.5 \mu \mathrm{M}\right)$. The most active compound was compound $\mathbf{1 6}\left(\mathrm{IC}_{50}=17.4 \mu \mathrm{M}\right)$ being four times more active than ascorbic acid, whereas AME $\left(\mathrm{IC}_{50}=12.67 \mu \mathrm{g} / \mathrm{mL}\right)$ exhibited similar activity to that of Ascorbic acid $\left(\mathrm{IC}_{50}=12.95 \pm 0.77 \mu \mathrm{g} / \mathrm{mL}\right)$.

\subsubsection{SOD Radical Scavenging Activity}

Superoxide anion radicals are the early radicals with basic role in the formation of ROS as previously reported [54]. Our results showed that AME exert the highest ability to inhibit $\mathrm{O}_{2}{ }^{-}$radical with $\mathrm{IC}_{50}=0.50 \mu \mathrm{g} / \mathrm{mL}$, which is nearly twenty folds that of ascorbic acid $\left(\mathrm{IC}_{50}=21.62 \mu \mathrm{g} / \mathrm{mL}\right)$. Furthermore, all pure compounds exhibited superior $\mathrm{O}_{2}{ }^{-}$ radical scavenging activity to that of ascorbic acid, (Table 4).

Several mechanisms have been suggested for the antioxidant activity exhibited by flavonoids being as: suppression of ROS formation, which could be through inhibition of enzymes or chelation of trace elements involved in the free radical generation; scavenging of ROS, or protection of antioxidant defense systems [54,55]. Moreover, some effects mediated by flavonoids may be owing to a combination between their radical scavenging activity and their ability to inhibit enzymes involved in ROS generation [56]. Furthermore, flavonoids act on cell signaling pathways, inhibit expression of pro-oxidative enzymes as microsomal monooxygenase, mitochondrial succinoxidase, NADH oxidase and lipoxygenases (LOX) as well as inducing expression of anti-oxidative enzymes (e.g., catalase, superoxide dismutase) [57].The antioxidant activity exhibited by flavonoids depends on several structural features like the arrangement of functional groups, the configuration and substitution, in addition to, the total number of hydroxyl groups, which significantly affect different antioxidant capability mechanisms as radical scavenging and metal ion chelation ability $[58,59]$. Correspondingly, the hydroxyl group configuration on the B ring; especially its catechol structure represents the most significant determinant for ROS scavenging as it can donate a hydrogen and an electron to peroxyl, hydroxyl, superoxide, and peroxynitrite radicals, stabilizing them and forming relatively stable flavonoids radical [58-60]. Additionally, different reports showed that flavonoids having an unsaturated 2-3 bond in conjugation with a 4-oxo function and the conjugation between the $\mathrm{A}$ and $\mathrm{B}$ rings also exhibited potent antioxidant activities. Our study showed that the nucleus of compounds identified from $\mathrm{AME}$ of $C$. viminalis was mainly based on quercetin and kaempferol nucleus, which have the above-mentioned structure features allowing them to exert a strong antioxidant activity as revealed in our results. Many reports mentioned the antioxidant activity of quercetin [19,61], and kaempferol [19]. Moreover, the AME showed to contain other 
compounds as gallic acid [62-64], methyl gallate [64-66], ellagitannins [67], caffeic acid [68], chlorogenic acid [69], and ellagic [70], which all possess strong antioxidant activity.

\subsection{Cytotoxic Activities of AME and the Pure Isolated Compounds against MCF-7 and HepG2 Cell Lines}

Cancer is considered as one of the top leading causes of death all over the world and according to the WHO (2015) [71] Breast cancer is one of the four major cancer types and it represents the highest incidence rate as well as the second-highest cause of death in females [71,72]. Additionally, hepatocellular cancer represents the sixth most frequent cancer and is the second leading cause of death [73]. The main difficulty in fighting cancer is the limited specificity of available chemical treatments. Thus, identifying new compounds with promising antitumor activity is extremely required, leading the researchers to seek for screening plants and isolation of natural compounds. Dietary flavonoids comprise many polyphenolic secondary metabolites with several pharmacological activities like their potential role as anti-cancer. A positive correlation between a diet rich in fruit and vegetables (and consequently rich in flavonoids) and lower risk of breast cancers, colon, and prostate cancers raised a question whether flavonoids can act as chemopreventive agents or can affect various genes and proteins to play role in chemotherapy [74]. There is a strong correlation between oxidative stress and the prevalence of cancer. Therefore, we investigated the anticancer activity of the AME and pure tested compounds 2-4, 7, 10, and 15-17 against MCF-7 and HepG2 cell lines using the MTT assay (Table 5). It was found that compounds 4,7 , and 16, showed strong anticancer activity against MCF-7 breast cancer cells $\left(\mathrm{IC}_{50}=127.4,101.0\right.$, and $132.5 \mu \mathrm{M}$, respectively), followed by 3 and $\mathbf{1 5}$ which displayed moderate activity in comparison to other compounds. While most of the compounds showed greater cytotoxic effect in the case of HepG2 cell line. Compounds 3, 7 , and 16 exhibited the strongest activity $\left(\mathrm{IC}_{50}=90.0 \mu \mathrm{M}\right.$ for compound 7 and $100.2 \mu \mathrm{M}$ for $3 \& 16$, respectively), whilst compounds 4,15 , and 17 showed strong to moderate activities with $\mathrm{IC}_{50}=125.9,132.5$, and $126.1 \mu \mathrm{M}$, respectively. Thus, the above-mentioned compounds may be a potential new antitumor and/or adjuvant treatment against liver and breast cancer. Since ROS can induce malignant cell transformation, thus, inhibition of ROS production can reverse cancer cell phenotype. Conclusively, polyphenolic compounds as kaempferol [75], quercetin [76], and their glycosides, tannins [67], and phenolic acids [77] can control cancer through their antioxidative activity. Therefore, the anticancer activity of AME and the isolated phenolic compounds may be attributed to their antioxidant activity.

Table 5. The anti-proliferative effect of the AME of the C. viminalis and pure compound against MCF-7 and HepG2 cell lines.

\begin{tabular}{ccc}
\hline Compound/Extract & IC $_{\mathbf{5 0}} \boldsymbol{\mu g} / \mathbf{m L} \pm \mathbf{S E M}\left(\mathbf{I C} \mathbf{5 0}_{\mathbf{\mu M})}\right.$ \\
\hline & MCF-7 Cell Line & HepG2 Cell Line \\
\hline $\mathbf{A M E}$ & $229.0 \pm 5.2$ & $214.0 \pm 5.8$ \\
$\mathbf{2}$ & $224.0 \pm 4.6(484.9)$ & $175.0 \pm 5.4(378.8)$ \\
$\mathbf{3}$ & $85.1 \pm 3.1(190.0)$ & $44.9 \pm 2.8(100.2)$ \\
$\mathbf{4}$ & $60.9 \pm 1.8(127.4)$ & $60.2 \pm 2.7(125.9)$ \\
$\mathbf{7}$ & $62.0 \pm 1.9(101.0)$ & $53.5 \pm 3.1(90.0)$ \\
$\mathbf{1 0}$ & $124.0 \pm 2.9(268.4)$ & $142.0 \pm 5.2(307.4)$ \\
$\mathbf{1 5}$ & $86.4 \pm 2.7(186.2)$ & $61.5 \pm 2.9(132.5)$ \\
$\mathbf{1 6}$ & $59.4 \pm 2.4(132.5)$ & $44.9 \pm 2.4(100.2)$ \\
$\mathbf{1 7}$ & $101.0 \pm 3.1(217.7)$ & $58.5 \pm 2.7(126.1)$
\end{tabular}

Data are displayed as mean \pm SEM of $\mathrm{IC}_{50}$ of three experiments. Value between () is $\mathrm{IC}_{50}$ in $\mu \mathrm{M}$.

\subsection{In Silico Analysis for the Antioxidant Effect}

The inhibition of 5-LOX could be a potential therapeutic pathway to treat and prevent cancer formation via inhibiting several oxidative and inflammatory processes. Recently, some crystal structures of human stable-5-LOX in bound to different natural products were resolved [78]. One of these is the crystal structure of nordihydroguaiaretic acid 
(NDGA) occupying the 5-LOX active site. NDGA is one of the plant polyphenols that has antioxidant properties and was found to inhibit 5-LOX. NDGA is believed to inhibit 5-LOX by binding into the 5-LOX active site and preventing the oxidative conversion process of $\mathrm{Fe}^{2+}$ to $\mathrm{Fe}^{3+}$ that activates the enzyme. Many natural and synthetic compounds with redox and non-redox activity can inhibit 5-LOX enzyme. Ascorbic acid is considered one of the most potent, naturally occurring, water-soluble antioxidant that has been widely studied for the treatment of several inflammatory conditions because of its strong antioxidant property [79]. In addition, it was found that quercetin is the most potent natural flavonoid against 5-LOX [80]. In this study, a thorough molecular docking inside the 5-LOX active site was performed on compounds 2, 3, 7, 16, 17, ascorbic acid and quercetin. The molecular docking was performed by AutoDock Vina [81] using the crystal structure of human stable-5-LOX in bound to NGDA (PDB: 6N2W). Validation for the docking parameters was performed by re-docking NGDA inside the active site of 5-LOX. The binding mode was assessed by comparing the modeled structure's binding mode to that of the crystal structure. It was found that the modeled structure of NDGA overlays on its crystal structure forming the same interactions (see Supplementary Materials). Reference drugs, i.e., ascorbic acid and quercetin, were also docked inside the 5-LOX binding site. The docking of ascorbic acid resulted in 9 conformers with affinity ranging from -4.6 to $-4.9 \mathrm{kcal} / \mathrm{mol}$. Ascorbic acid was found to fit nicely in the active site forming multiple $\mathrm{H}$-bonds with proximal amino acid (Figure 3a): Gln363 (3.13 $\AA), \operatorname{Pro569}(2.99 \AA)$, Arg595 (3.02 $\AA, 3.05 \AA$ and $3.15 \AA$ ) and His600 (3.01 $\AA$ ). Moreover, quercetin was docked as well inside the 5-LOX active site; 9 conformers were also obtained with binding affinity ranging from -6.0 to $-7.2 \mathrm{kcal} / \mathrm{mol}$. Quercetin interactions inside the 5-LOX active site are as follows: 1) H-bonds with Gln363

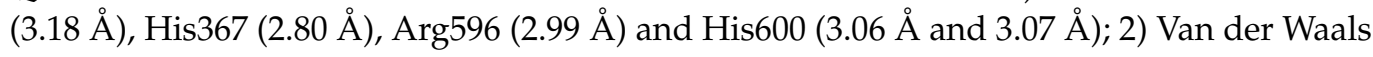
interactions with Phe359, Trp599 and Ala603 (Figure 3b).
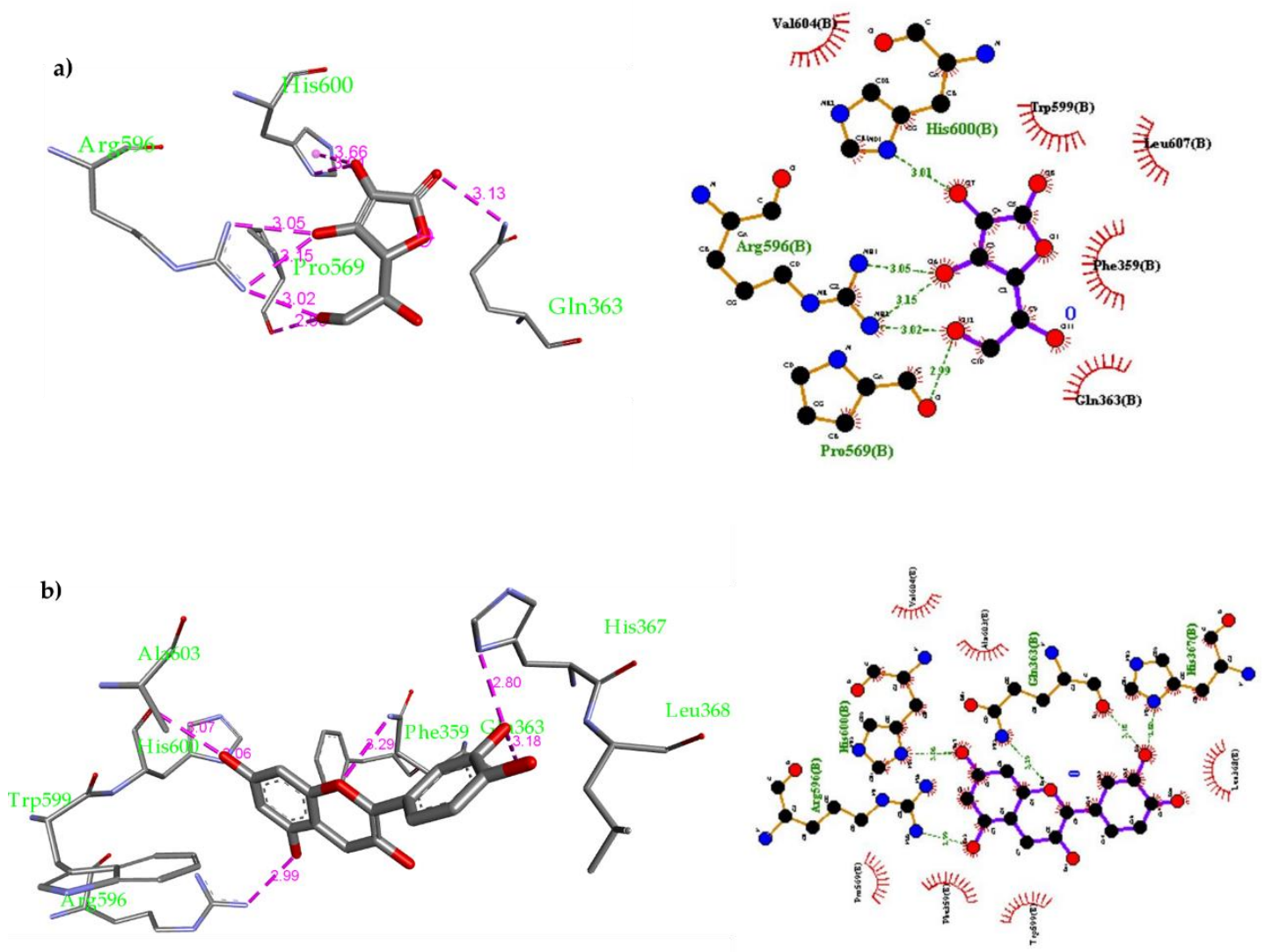

Figure 3. (a) Docking of Ascorbic acid inside the 5-LOX active site and 2-D schematic representation for the non-covalent interactions of ascorbic inside 5-LOX active site; (b) Docking of Quercetin inside the 5-LOX active site and 2-D schematic representation for non-covalent interactions formed by quercetin inside the 5-LOX active site. 
Compound 2 was docked inside the 5-LOX active site using the same parameters and 9 possible conformers were obtained with higher affinity than ascorbic acid ranging from -7.1 to $-8.0 \mathrm{kcal} / \mathrm{mol}$. Compound 2 was found to form several non-covalent interactions inside the 5-LOX active site (Figure 4a): (1) H-bonds with His367 (3.19 ̊), Gln363 (2.87 and $3.14 \AA$ ) and His600 (3.10 ̊); (2) Van der Waals interactions with Leu368, Ala410, Trp599 and Leu607. Additionally, Compound 3 was docked inside the 5-LOX and 9 conformers were obtained with moderate affinity ranging from -6.4 to $-7.4 \mathrm{kcal} / \mathrm{mol}$ (see Supplementary Materials). Furthermore, compound 7 was also docked, and 9 conformers were obtained with better affinity ranging from -6.9 to $-8.1 \mathrm{kcal} / \mathrm{mol}$. Several non-covalent interactions were formed between compound 7 and the 5-LOX amino residues (Figure 4b): (1) multiple H-bonds with Gln363 (2.70 ̊), His367 (3.02 and $3.59 \AA$ ) and Leu414 (3.02 ̊); (2) Van der Waals interactions with Ala410, Leu414 and Trp599. Compound 16 was docked inside the 5-LOX active site and 9 conformers were obtained with strong affinity ranging from -7.2 to $-8.3 \mathrm{kcal} / \mathrm{mol}$. This compound was found to have the best fitting among all compounds docked.
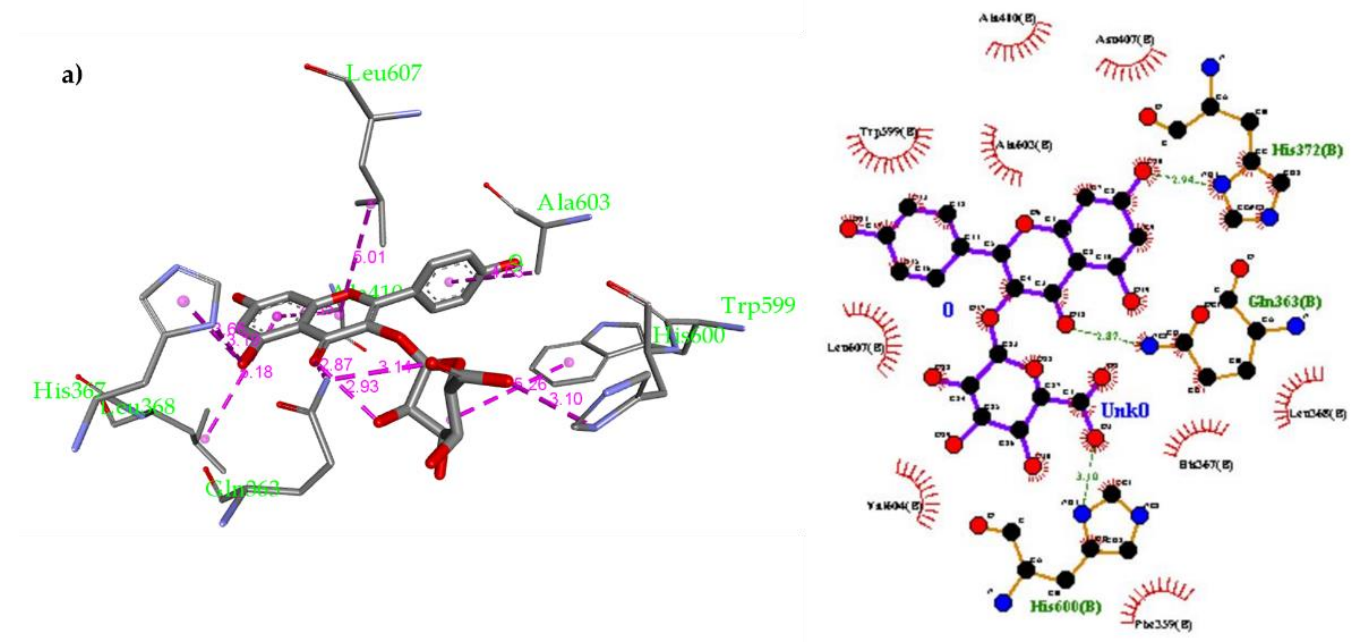

b)

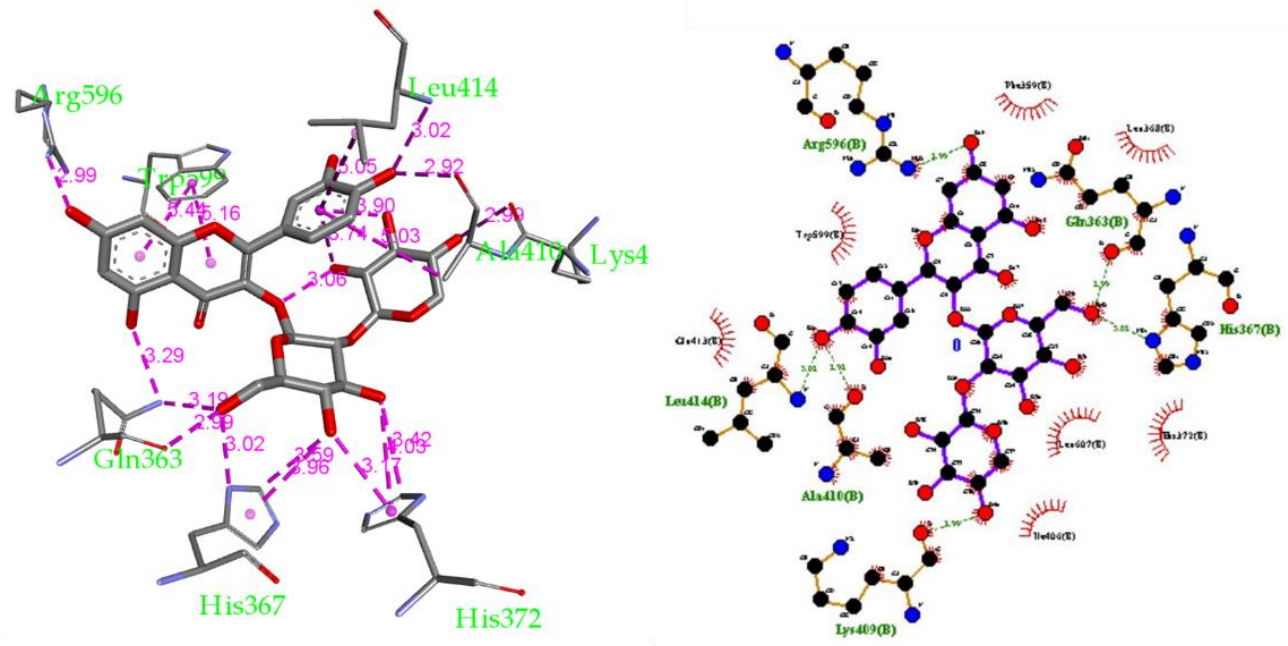

Figure 4. (a) Docking of compound 2 inside the 5-LOX active site and 2-D schematic representation for its non-covalent interactions inside 5-LOX active site; (b) Docking of compound 7 inside the 5-LOX active site and 2-D schematic representation for its non-covalent interactions inside the 5-LOX active site.

Compound 16 was found to form more non-covalent interactions than others (Figure 5b): (1) H-bonds with Gln363 (3.05 and $3.12 \AA$ ), Thr364 (2.81 ̊), His367 (3.12 ̊) and Pro569 
(2.51 ̊̊), Arg596 (3.03 ̊); (2) Van der Waals interactions with Phe359, Trp599, Ala603 and Leu607. In addition, compound $\mathbf{1 7}$ was docked as well and 9 conformers were obtained with affinity ranging from -6.9 to $-8.1 \mathrm{kcal} / \mathrm{mol}$. This compound was found to have good fitting inside the 5-LOX active site. Compound 17 was found to form several non-covalent interactions (Figure 5b): (1) H-bonds with His367 (2.64 $⿱$ )), Arg596 (3.07 and $3.38 \AA$ ) and His600 (3.13 ̊); (2) Van der Waals interactions with His372, Ile406, Ala410 and Leu607. The docking results suggest that all the six polyphenolic compounds are well-fitted inside the human 5-LOX active site and exert binding affinity greater (more favorable) than ascorbic acid and quercetin. It is expected that these compounds will exhibit a good in vitro profile for inhibiting human 5-LOX through occupying its active site preventing the conversion of $\mathrm{Fe}^{2+}$ to $\mathrm{Fe}^{3+}$ that activates the enzyme. Additionally, compound $\mathbf{1 7}$ has a good chance to further in vivo use as it could survive through human digestion, get absorbed then inhibit human 5-LOX at its site of action.
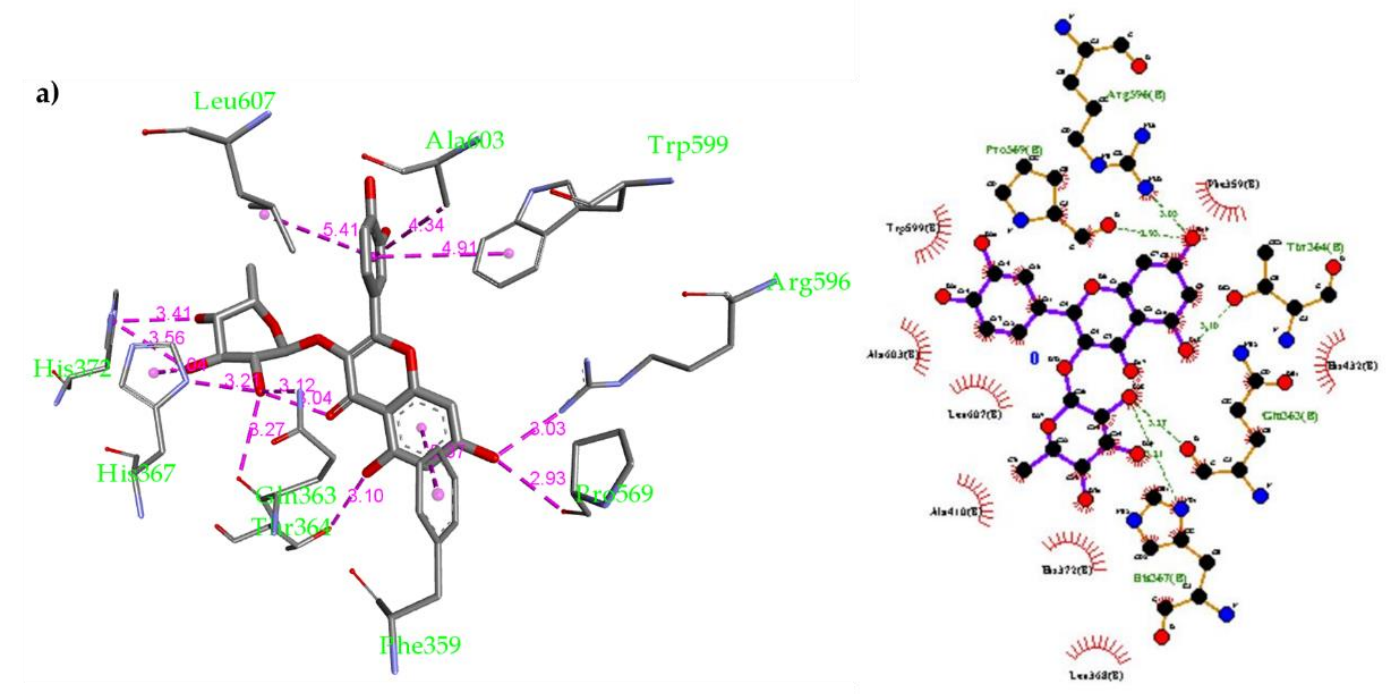

b)
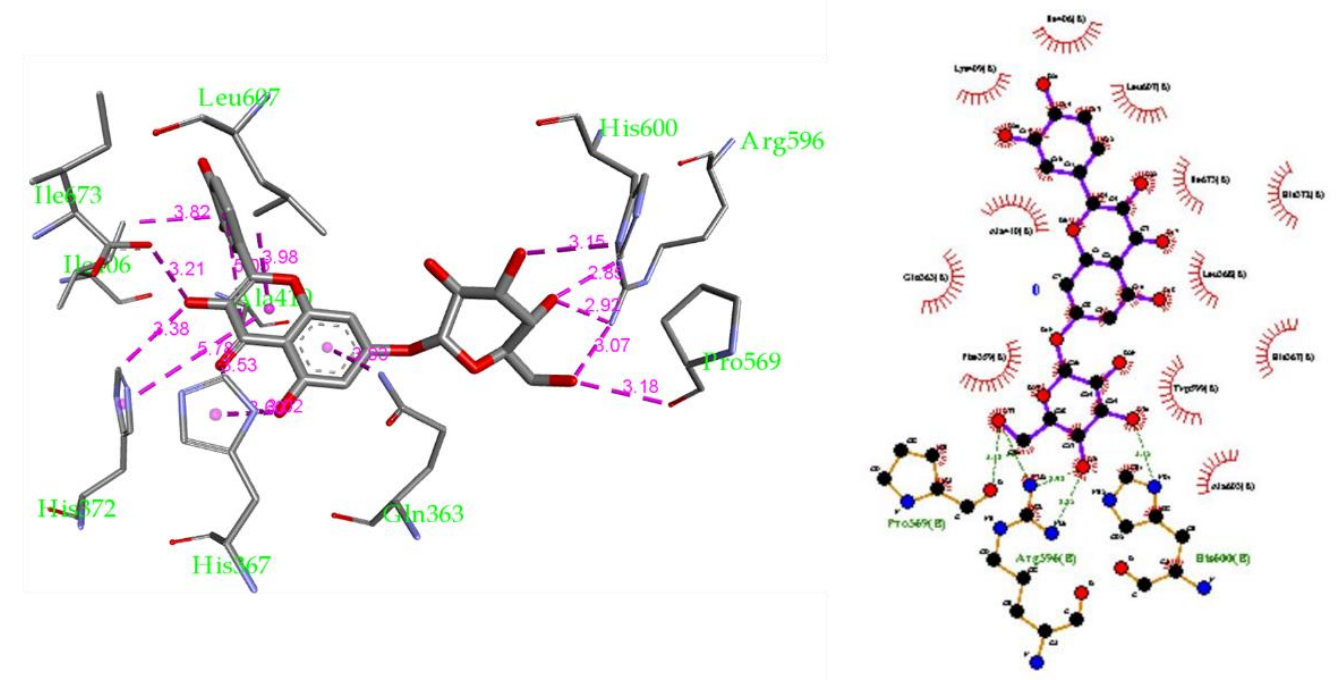

Figure 5. (a) Docking of compound 16 inside the 5-LOX active site and 2-D schematic representation for its non-covalent interactions inside 5-LOX active site; (b) Docking of compound 17 inside the 5-LOX active site and 2-D schematic representation for its non-covalent interactions inside the 5-LOX active site. 


\section{Materials and Methods}

\subsection{General Experimental Data}

The NMR data were recorded on Bruker Avance spectrometers (400 and 500 for ${ }^{1} \mathrm{H}$ NMR and 100 and $125 \mathrm{MHz}$ for 13C NMR). The results were expressed as $\delta$ ppm values relative to the internal reference (TMS). ESI-MS was done on a Xevo TQD Triple quadrupole (Water Corporation, Milford, USA). Column chromatography (CC) was carried out using Polyamide S (Fluka Chemie AG, Buchs, Switzerland), Sephadex LH-20 (Sigma-Aldrich, Steinheim, Germany), and microcrystalline cellulose (Merck, Darmstadt, Germany). Whatman No.1 paper sheets (Whatman Ltd., Maidstone, Kent, UK), silica gel F254, and cellulose plates $(0.2 \mathrm{~mm}$, Merck, Darmstadt, Germany) were used for qualitative identification of the fractions and pure compounds.

n-Butanol: acetic acid: water, [4:1:5 (BAW), top layer, $\left.\mathrm{S}_{1}\right], 15 \%$ acetic acid $\left(\mathrm{S}_{2}\right)$ and n-butanol: isopropyl: water, [4:1:5 (BIW), top layer, $S_{3}$ ] were used for elution of compounds on a thin layer (TLC), paper (PC) and column chromatography. Naturstoff [82], $\mathrm{FeCl}_{3}$, $\mathrm{NH}_{3}, \mathrm{NaNO}_{2}$ [83], glacial $\mathrm{AcOH}$, and aniline hydrogen phthalate [84] are representing the spray reagents used for the visualization of the pure compounds.

Authentic samples of flavonoids (kaempferol 3-O- $\beta$-D-rhamnopyranoside, kaempferol and quercetin), phenolic acids (chlorogenic acid, ellagic acid, gallic, methyl gallate, and caffeic acid), and sugars (purity 95\%) were obtained from the Pharmacognosy Department, Faculty of Pharmacy, Helwan University, Helwan, Cairo, Egypt. Dichloromethane, ethanol, ethyl acetate, methanol, butanol, petroleum ether and acetic acid, dimethyl sulfoxide (DMSO) are of analytical grade and obtained from El Nasr Pharmaceutical Chemicals Co (Cairo, Egypt).

2,2-diphenyl-1-picrylhydrazyl radical (DPPH), pyrogallol, sodium nitroprusside, Griess reagent (1\% of sulphanilamide and $0.1 \%$ of naphthyl ethylenediamine in $2.5 \%$ $\mathrm{H}_{3} \mathrm{PO}_{3}$ ), ascorbic acid and MTT (3-[4, 5-dimethylthiazol-2-yl]-2, 5-diphenyl tetrazolium bromide) were purchased from Sigma-Aldrich (Steinheim, Germany). Fetal bovine serum, RPMI 1640 medium, HEPES buffer solution, L-glutamine, gentamycin, and 0.25\% TrypsinEDTA were supplied from Lonza bioscience (Basel, Switzerland). Human cancer cell lines: breast cancer cell lines (MCF-7) and hepatocellular carcinoma cell lines (HepG-2) were obtained from VACSERA Tissue Culture Unit (Giza, Egypt).

\subsection{Plant Material}

Callistemon viminalis (Sol. ex Gaertn.) G.Don. (Syn, Melaleuca viminalis (Sol. ex Gaertn. Metrosideros viminalis (Sol. ex Gaertn.) Byrnes. The aerial parts were collected from El Qanater El Khayreya, Qalyubia, Egypt during the flowering stage (December 2016). The plant was taxonomically identified by Dr. Trease Labib, former specialist of plant Taxonomy at El Orman Botanical Garden, Giza, Egypt. Voucher specimens (16 Mvi1/2016) were placed in the Pharmacognosy Department Herbarium, Faculty of Pharmacy, Helwan University, Cairo, Egypt.

\subsection{Extraction and Isolation}

Aerial parts of $C$. viminalis $(1.7 \mathrm{~kg})$ were dried, ground to a small size, and then extracted with $80 \%$ aqueous methanol $(3 \times 5 \mathrm{~L})$ giving $442.5 \mathrm{~g}$ dry extract after solvent evaporation under vacuum. The obtained dry extract was defatted with petroleum ether $\left(60-80{ }^{\circ} \mathrm{C}\right)$, followed by evaporation of solvents to give 150.5 and $275.5 \mathrm{~g}$ of petroleum ether and aqueous residue, respectively. For purification of the extract from sugar and salts, the dried aqueous extract $(275.5 \mathrm{~g})$ was dissolved in the least amount of water and precipitated with excess ethanol (1:10 v/v), after filtration the ethanol-soluble portion was evaporated leaving $175 \mathrm{~g}$ dry crude extract. The dried crude extract was found to be rich in polyphenolics based on its 2-D-PC using $\mathrm{S}_{1}$ and $\mathrm{S}_{2}$ systems and visualization under UV light and spraying with Naturstoff, $\mathrm{NH}_{3}, \mathrm{NaNO}_{2}$-glacial $\mathrm{AcOH}$, and $\mathrm{FeCl}_{3}$ reagents. For isolation of the compounds $100 \mathrm{~g}$ from $\mathrm{AME}$, it was subjected to fractionation on polyamide column ( 300 g polyamide, $120 \times 5 \mathrm{~cm}$ ) using gradient elution with $\mathrm{H}_{2} \mathrm{O}-\mathrm{MeOH}$ mixtures 
(100:0-0:100\%) to obtain 105 individual fractions (each $1 \mathrm{~L}$ ). They were collected into ten collective fractions (I-X), depending on their chromatographic behavior on TLC and PC using UV light and different spraying reagents. Fraction $1\left(100 \% \mathrm{H}_{2} \mathrm{O}, 10 \mathrm{~g}\right.$ contained traces of phenolic compounds. Fraction II $\left(10 \% \mathrm{MeOH}: \mathrm{H}_{2} \mathrm{O}, 6 \mathrm{~g}\right)$ was fractionated on a Sephadex LH-20 column and eluted with $S_{3}$ to yield three subfractions (i, ii, iii). First, subfraction was subjected to repeated Sephadex LH-20 column using $\mathrm{S}_{3}$, followed by $50 \%$ $\mathrm{MeOH}: \mathrm{H}_{2} \mathrm{O}$ to give a pure sample of $\mathbf{1}(19 \mathrm{mg})$ and $6(5 \mathrm{mg})$. The second subfraction was applied on Sephadex LH-20 using $S_{3}$ yielding $2(20 \mathrm{mg})$ and $7(25 \mathrm{mg})$ while the last subfraction revealed a pure sample of $8(10 \mathrm{mg})$ by precipitation from its methanol solution. Fraction III (20-30\% MeOH: $\left.\mathrm{H}_{2} \mathrm{O}, 4 \mathrm{~g}\right)$ was subjected to fractionation on cellulose column and $S_{3}$ as eluent resulted in two subfractions, the first was applied on Sephadex LH-20 and $S_{3}$ as eluent to yield a chromatographically pure sample of 9 (12 mg) and 10 (15 mg). Moreover, compounds $11(5 \mathrm{mg})$ and $\mathbf{1 2}(5 \mathrm{mg})$ were purified from the second subfraction using PPC and $\mathrm{S}_{2}$ as eluent. Fractionation of IV (40\% $\left.\mathrm{MeOH}: \mathrm{H}_{2} \mathrm{O}, 3.5 \mathrm{~g}\right)$ on cellulose column and elution with $S_{3}$ resulted in two subfractions, the first gave a pure sample of 3 (20 mg) after application on Sephadex column (MeOH: $\left.\mathrm{H}_{2} \mathrm{O}, 10-100 \%\right)$, while the second was subjected to repeated Sephadex columns and elution with $\mathrm{S}_{3}$, followed by $\mathrm{MeOH}: \mathrm{H}_{2} \mathrm{O}$ (50\%) to yield a pure sample of $4(22 \mathrm{mg})$ and $13(8 \mathrm{mg})$. Fraction V $\left(40 \% \mathrm{MeOH}: \mathrm{H}_{2} \mathrm{O}\right.$, $3.0 \mathrm{~g}$ ) was applied on repeated cellulose and Sephadex columns using $\mathrm{S}_{3}$ as eluent which revealed a chromatographically pure sample of $14(15 \mathrm{mg})$ and $15(10 \mathrm{mg})$. Compounds 5 $(15 \mathrm{mg})$ and 15 (25 mg) were isolated from fraction VI (50-60\% MeOH: H2O, $2.5 \mathrm{~g}$ ) after application on cellulose column and $S_{3}$ for elution, followed by repeated Sephadex columns using $\mathrm{S}_{3}$ and $\mathrm{MeOH}: \mathrm{H}_{2} \mathrm{O}(50 \%)$ as eluents. Fraction VII (60-70\% MeOH: $\left.\mathrm{H}_{2} \mathrm{O}, 2.0 \mathrm{~g}\right)$ was subjected to fractionation on cellulose column $\left(S_{3}\right)$, then Sephadex column $\left(S_{3}\right)$ to give a chromatographically pure sample of $17(15 \mathrm{mg})$ and $18(5 \mathrm{mg})$. Fractions VIII (3 mg) and IX (2 mg) contained a complicated mixture and so remained under investigation. A pure sample of $19(5 \mathrm{mg})$ and $20(3 \mathrm{mg})$ were isolated from fraction $\mathrm{X}\left(100 \% \mathrm{MeOH}: \mathrm{H}_{2} \mathrm{O}, 1.5 \mathrm{~g}\right)$ by PPC using $S_{2}$ for elution.

Kaempferol 3-O-( $4^{\prime \prime}$-galloyl)- $\beta$-D-glucopyranosyl- $\left(1^{\prime \prime \prime} \rightarrow 6^{\prime \prime}\right)-\mathrm{O}-\beta$-D-glucopyranoside (1). The pure isolated compound is a yellow amorphous powder with $\operatorname{Rf}$ value $S_{1}(0.60)$ and $S_{2}(0.48) .{ }^{1} \mathrm{H}$ and ${ }^{13} \mathrm{C}$ NMR data (400 and $100 \mathrm{MHz}$, DMSO- $d_{6}$ ) are presented in Table 1 , Supplementary Materials Figures S1-S4.

Kaempferol 3-O- $\beta$-D-mannuronopyranoside (2). It was purified as a yellow amorphous powder with Rf value $S_{1}(0.44)$ and $S_{2}(0.47)$; Negative HRESI MS m/z 461.1359 [M - H] ${ }^{-}$calculated for $\mathrm{C}_{21} \mathrm{H}_{18} \mathrm{O}_{12}, 923.2622$ [2M $\left.-\mathrm{H}\right]^{-}, 285.0885\left[\mathrm{M}-176\right.$; kaempferol] ${ }^{-} .{ }^{1} \mathrm{H}$ and ${ }^{13} \mathrm{C} \mathrm{NMR}(400$ and $100 \mathrm{MHz}$, DMSO- $d_{6}$ ), Table 2, Supplementary Materials Figures S5-S7.

Kaempferol 3-O- $\beta$-D-mannopyranoside (3). It was isolated as a yellow amorphous powder; Rf; $\mathrm{S}_{1}(0.55)$ and $\mathrm{S}_{2}(0.49)$ Negative HRESIMS $\mathrm{m} / \mathrm{z} 447.0941[\mathrm{M}-\mathrm{H}]^{-}$, calculated for $\mathrm{C}_{21} \mathrm{H}_{20} \mathrm{O}_{11}, 895.3108[2 \mathrm{M}+\mathrm{H}]^{-},{ }^{1} \mathrm{H}$ and ${ }^{13} \mathrm{C}$ NMR data (400 and $100 \mathrm{MHz}, \mathrm{DMSO}-d_{6}$ ) are presented in Table 2, Supplementary Materials Figures S8-S10.

Quercetin 3-O- $\beta$-D-mannuronopyranoside (4). Yellow amorphous powder; $\mathrm{Rf}$ value $\mathrm{S}_{1}(0.76)$; $\mathrm{S}_{2}(0.52) ;{ }^{1} \mathrm{H}$ NMR (400 MHz, DMSO-d 6 ) $\delta 12.42(\mathrm{OH}-5), 7.48\left(\mathrm{dd}, \mathrm{br} \mathrm{s}, J=7.2 \mathrm{~Hz}, \mathrm{H}-6^{\prime}\right)$, 7.89 (br s, H-2'), 6.84 (d, J = 7.2, H-5'), 6.40 (br s, H-8), 6.19 (br s, H-6), 5.35 (d, J = 2.0 H-1 ${ }^{\prime \prime}$ ), 3.59-3.27 (remaining sugar protons). ${ }^{13} \mathrm{C}$ NMR (100 MHz, DMSO-d $\left.d_{6}\right), \delta 177.8(\mathrm{C}-4), 171$. $9\left({\mathrm{C}-6^{\prime \prime}}^{\prime \prime}\right), 164.9(\mathrm{C}-7), 161.5$ (C-5), 157.2 (C-2), 156.8 (C-9), $148.9\left(\mathrm{C}-4^{\prime}\right), 145.3\left(\mathrm{C}-3^{\prime}\right), 133.9$ (C-3), $122.8\left(\mathrm{C}-6^{\prime}\right), 121.9\left(\mathrm{C}-1^{\prime}\right), 117.2\left(\mathrm{C}-2^{\prime}\right), 115.8\left(\mathrm{C}-5^{\prime}\right), 104.2(\mathrm{C}-10), 102.2\left(\mathrm{C}-1^{\prime \prime}\right), 99.3(\mathrm{C}-6)$, $\left.94.2(\mathrm{C}-8), 76.7\left(\mathrm{C}-5^{\prime \prime}\right), 74.3\left(\mathrm{C}-3^{\prime \prime}\right), 74.3 \mathrm{C}-2^{\prime \prime}\right), 71.9\left(\mathrm{C}-4^{\prime \prime}\right)$, Negative HRESIMS m/z 477.1472 $[\mathrm{M}-\mathrm{H}]^{-}$(calculated for $\mathrm{C}_{21} \mathrm{H}_{18} \mathrm{O}_{13}, 477.1472$ ), $955.2128[2 \mathrm{M}-\mathrm{H}]^{-}, 301.1082$ [M-176; $^{-}$ aglycone $]^{-}$, Supplementary Materials Figures S11-S13.

2,3 (S)-hexahydroxydiphenoyl]-D-glucose (5). It was isolated as off-white powder; Rf value $\mathrm{S}_{1}$ (0.03), $\mathrm{S}_{2}(0.44)$; Negative HRESIMS $m / z 481.0970[\mathrm{M}-\mathrm{H}]^{-}$(calculated for $\mathrm{C}_{20} \mathrm{H}_{18} \mathrm{O}_{14}$, 
481.0970). ${ }^{1} \mathrm{H}$ and ${ }^{13} \mathrm{C}$ NMR (400 and $100 \mathrm{MHz}$, DMSO- $d_{6}$ ) refer to Table 3 Supplementary Materials Figures S14-S18.

\subsection{In Vitro Antioxidant Assays}

\subsubsection{2,2-Diphenyl-1-picrylhydrazyl (DPPH) Radical Scavenging Activity}

It was performed according to the method reported by [85]. In Brief, $100 \mu \mathrm{L}$ of serially diluted $(12.5,25,50,100$, and $200 \mu \mathrm{g} / \mathrm{mL})$ AME and pure compounds, ascorbic acid and DMSO as a positive and negative control, respectively were added to $100 \mu \mathrm{L}$ methanolic solution of DPPH. After vigorous shaking, the mixture was placed in the dark $\left(25^{\circ} \mathrm{C}\right.$, $30 \mathrm{~min}$ ) followed by absorbance determination at $\lambda 517 \mathrm{~nm}$. The experiment was performed in three replicates. The antioxidant activity was expressed as DPPH inhibition percentage (I\%) as follows:

$\mathrm{I} \%=\left[\left(\mathrm{Abs}_{\text {control }}-\mathrm{Abs}_{\text {sample }}\right) / \mathrm{Abs}_{\text {control }}\right] \times 100$, where $\mathrm{Abs}_{\text {control }}$ and Abs sample are the control and sample absorbance, respectively. $\mathrm{IC}_{50}$ was calculated using nonlinear regression analysis from the curves plotted between the percentage of DPPH inhibition versus log concentration of sample or ascorbic acid.

\subsubsection{Antioxidant Capacity Determined by Nitric Oxide (NO) Scavenging Assay}

The scavenging activity of the AME and pure compounds against nitric oxide was evaluated according to Ebrahimzadeh et al. [86], using ascorbic acid as a reference standard. $50 \mu \mathrm{L}$ of different concentrations of the tested samples were pipetted into a 96-well plate followed by the addition of sodium nitroprusside ( $50 \mu \mathrm{L}$ of $10 \mathrm{mM}$ in PBS, $\mathrm{pH}$ 7.4) to each well. The plates were incubated for $90 \mathrm{~min}$ at room temperature, followed by the addition of an equal volume of Griess reagent. The absorbance of the developed color was measured at $\lambda 546 \mathrm{~nm}$. All measurements were performed in triplicates. The percentage of NO inhibition and $\mathrm{IC}_{50}$ were calculated as in the case of the DPPH method.

\subsubsection{Antioxidant Capacity Determined by Superoxide Radical $\left(\mathrm{O}_{2}{ }^{-}\right)$Scavenging Assay}

Measurement of superoxide radical scavenging capacity of AME and the pure compounds was done using a previously reported method [87]. Ascorbic acid and DMSO were used as the positive and negative control, respectively. In Brief, $50 \mu \mathrm{L}$ of each sample concentration were added to $2900 \mu \mathrm{L}$ of $5 \mathrm{mM}$ Tris $\mathrm{HCl}$ buffer $(0.05 \mathrm{M}, \mathrm{pH} 7.4)$ containing $1 \mathrm{mM} \mathrm{Na}{ }_{2}$ EDTA. Then, $50 \mu \mathrm{L}$ of $60 \mathrm{mM}$ pyrogallol in $1 \mathrm{mM} \mathrm{HCl}$ was added to the mixture. The absorbance of the reaction mixture was measured every $30 \mathrm{~s}$ for $5 \mathrm{~min}$ at $\lambda 325 \mathrm{~nm}$. All measurements were performed in triplicates and the percentage of $\mathrm{O}_{2}{ }^{-}$inhibition and $\mathrm{IC}_{50}$ were calculated as in the case of the previous antioxidant assay methods.

\subsection{In Vitro Cytotoxic Activity}

Cytotoxic activities of the AME and pure compounds were tested against Human Breast (MCF-7) and Hepatocellular carcinoma (HepG2) cancer cell lines using the microculture tetrazolium (MTT) assay and compared to that of untreated controls [88]. The cells were propagated in Dulbecco's modified Eagle's medium (DMEM) supplemented with $10 \%$ heat-inactivated fetal bovine serum, $1 \%$ L-glutamine, HEPES buffer, and $50 \mu \mathrm{g} / \mathrm{mL}$ gentamycin. All cells were maintained at $37{ }^{\circ} \mathrm{C}$ in a humidified atmosphere with $5 \% \mathrm{CO}_{2}$ and were sub-cultured two times a week. For cytotoxicity assay, cells $\left(1 \times 10^{4}\right.$ cells / well $)$, in the growth medium, were seeded in a 96-well microplate and treated with tested pure compounds and the extract (100 $\mu \mathrm{l}$ medium/well) at different concentrations (500, 250, $125,62.5,31.25,15.6,7.8$ and $3.9 \mu \mathrm{g} / \mathrm{mL}$ in DMSO), then incubated for $24 \mathrm{~h}$ at $37^{\circ} \mathrm{C}$, in a humidified $5 \% \mathrm{CO}_{2}$ atmosphere. After incubation, media were removed and $40 \mu \mathrm{L}$ MTT solution/well was added and incubated for an additional $4 \mathrm{~h}$. MTT crystals were solubilized by the addition of $180 \mu \mathrm{L}$ of DMSO to each well and left at room temperature for $45 \mathrm{~s}$. The presence of viable cells was visualized by the development of purple color due to the formation of formazan crystals. The absorbance was measured at $\lambda 570 \mathrm{~nm}$ using a microplate reader (Sunrise, TECAN, Inc., CA, USA). Triplicate repeats were performed for 
each concentration. Data were expressed as the percentage of relative viability compared with the untreated cells and with the vehicle control (DMSO), with cytotoxicity indicated by $<100 \%$ relative viability. The relation between surviving cells and drug concentration is plotted to get the survival curve of each tumor cell line after treatment with the specified compound. The half-maximal inhibitory concentration of viability $\left(\mathrm{IC}_{50}\right)$ was calculated from the dose-response curve using nonlinear regression analysis.

\subsection{Data Analysis}

$\mathrm{IC}_{50}$ was calculated by using nonlinear regression analysis using Graph Pad Prism version 5 for windows (Graph Pad Inc., CA, USA). All experiments were carried out in triplicate and data were presented as mean \pm SEM, using Graph Pad InStat (Graph software Inc., V 3.05, Ralph Stahlman, Purdue University, Lafayette, IN, USA).

\subsection{Molecular Modeling Procedure}

The crystal structure of the human stable 5-LOX (PDB: 6N2W) co-crystallized with NDGA (PDB ID: 1M17) was used for the docking analysis. 3D structures of Polyphenolic compounds as well as reference drugs (ascorbic acid and quercetin) were obtained using the Discovery Studio software (Accelrys Inc., San Diego, CA, USA). Auto Dock Tools (The Scripps Research Institute, La Jolla, CA, USA) was used to prepare the ligands and receptor as pdbqt files after removing water, adding polar hydrogen atoms and Gasteiger charges, respectively. The docking grid box size used was $40 \times 40 \times 40 \AA^{3}$, encompassing the entire 5-LOX binding pocket. An exhaustiveness value of 8 was used while keeping the other parameters with their default values. The best docking pose (most stable) was selected for binding mode comparison with that of reference drugs. Visualization of ligand-protein non-covalent interactions was performed using Discovery Studio software. The schematic 2-D representations of enzyme-ligand complexes was generated using LIGPLOT version 2.2.4 (European Molecular Biology Laboratory, Cambridge, UK).

\section{Conclusions}

Natural antioxidants have several important uses in health promotion through inhibition of oxidative stress, which is an important character of any medicinal plant. The results of this study revealed that AME of C. viminalis aerial parts afforded four new flavonol glycosides and one tannin compound along with fifteen known compounds mainly flavonol glycosides, phenolic acids, and aglycones. The antioxidant activity of the AME and some isolated pure compounds was investigated, and we found that most of the isolated compounds showed significant radical scavenging activities using different radical scavenging assays, which merit additional studies of their cytotoxic activities against breast (MCF-7) and hepatocellular (HepG2) cancer cells. In addition, a thorough in silico analysis for possible antioxidant mechanism of action of these compounds was performed using the crystal structure of human 5-LOX. Six compounds were docked into the active site and the binding affinity was compared to that of ascorbic acid and quercetin. All compounds showed proper binding inside the 5-LOX active site exerting more favorable binding than reference drugs. The in silico experiments suggest that all compounds herein will have a good in vitro 5-LOX inhibition profile with some compounds, i.e., compound $\mathbf{1 7}$ have the potential for further clinical development. The docking studies, in vitro antioxidant and anticancer evaluations suggest that these compounds could be used as dual antioxidant and anticancer agents.

Supplementary Materials: The following are available online. Supplementary data includes molecular modeling, as well as spectral data.

Author Contributions: Conceptualization, F.A.M., S.M. and A.M.S.; Methodology, N.H., S.A., S.M., R.I., A.M.S.; Software, S.M., M.M., A.M.S.; Formal Analysis, F.A.M., M.M., N.H., S.M., A.M.S.; Investigation, F.A.M., M.M., N.H., R.I., S.M., A.M.S.; Resources, N.H., S.A., R.I. and S.M.; Data Curation, F.A.M., M.M., A.M.S.; Writing—original draft preparation, F.A.M., M.M., S.M., A.M.S.; 
Writing-Review \& Editing, F.A.M., M.M., S.A., S.M., A.M.S.; Visualization F.A.M., S.M., M.M., A.M.S.; Supervision, F.A.M.; Project Administration, F.A.M. and N.H. All authors have read and agreed to the published version of the manuscript.

Funding: This research received no external funding.

Institutional Review Board Statement: Not applicable.

Informed Consent Statement: Not applicable.

Data Availability Statement: The data presented in this study are available on request from the corresponding author.

Acknowledgments: We would like to thank colleagues at Faculty of Pharmacy, Helwan University for help and support.

Conflicts of Interest: The authors declare no conflict of interest.

Sample Availability: Samples of the known compounds are available from the authors.

\title{
Abbreviations
}

\author{
$\mathrm{HCl} \quad$ Hydrochloric acid; \\ HepG2 Hepatoma G2 cell line; \\ $\mathrm{IC}_{50}$ Concentrations of tested compounds that give about $50 \%$ inhibition of cell viability \\ MCF-7 Michigan Cancer Foundation-7 cell line; \\ MS Mass Spectrometry; \\ NMR Nuclear Magnetic Resonance;
}

\section{References}

1. Salem, M.Z.M.; El-Hefny, M.; Nasser, R.A.; Ali, H.M.; El-Shanhorey, N.A.; Elansary, H.O. Medicinal and biological values of Callistemon viminalis extracts: History, current situation and prospects. Asian Pac. J. Trop. Med. 2017, 10, 229-237. [CrossRef]

2. Ahmad, K.; Athar, F. Phytochemistry and pharmacology of Callistemon viminalis (Myrtaceae): A Review. Nat. Prod. J. 2017, 7, 166-175. [CrossRef]

3. Salem, M.Z.; Ali, H.M.; El-Shanhorey, N.A.; Abdel-Megeed, A. Evaluation of extracts and essential oil from Callistemon viminalis leaves: Antibacterial and antioxidant activities, total phenolic and flavonoid contents. Asian Pac. J. Trop. Med. 2013, 6, 785-791. [CrossRef]

4. Abd, J. Studying of antibacterial effect for leaves extract of Callistemon viminalis in vitro and vivo (urinary system) for rabbits. J. Kerbala Univ. 2012, 8, 246-254.

5. Ahmed, A.H. Phytochemical and cytotoxicity studies of Callistemon viminalis leaves extract growing in Egypt. Curr. Pharm. Biotechnol. 2020, 21, 219-225. [CrossRef] [PubMed]

6. El Dib, R.; El-Shenawy, S. Phenolic constituents and biological activities of the aerial parts of Callistemon viminalis (Sol. Ex Gaertner) G. Don ex Loudon. Bull. Fac. Pharm. 2008, 46, 223-235.

7. Gohar, A.A.; Maatooq, G.T.; Gadara, S.R.; Aboelmaaty, W.S. One new pyrroline compound from Callistemon viminalis (Sol. Ex Gaertner) G.Don Ex Loudon. Nat. Prod. Res. 2013, 27, 1179-1185. [CrossRef]

8. Wu, J.W.; Li, B.L.; Tang, C.; Ke, C.Q.; Zhu, N.L.; Qiu, S.X.; Ye, Y. Callistemonols A and B, potent antimicrobial acylphloroglucinol derivatives with unusual carbon skeletons from Callistemon viminalis. J. Nat. Prod. 2019, 82, 1917-1922. [CrossRef]

9. Wu, L.; Zhang, Y.; Wang, X.; Liu, R.; Yang, M.; Kong, L.; Luo, J. Acylphloroglucinols from the fruits of Callistemon viminalis. Phytochem. Lett. 2017, 20, 61-65. [CrossRef]

10. Liu, H.-X.; Chen, K.; Liu, Y.; Li, C.; Wu, J.-W.; Xu, Z.-F.; Tan, H.-B.; Qiu, S.-X. Callviminols AE, new terpenoid-conjugated phloroglucinols from the leaves of Callistemon viminalis. Fitoterapia 2016, 115, 142-147. [CrossRef]

11. Ahmad, K. 14P Evaluating anti-oxidant potential of Callistemon viminalis leaves extracts and their compounds in STAT 3 pathway in liver cancer. Ann. Oncol. 2017, 28, mdx652.013. [CrossRef]

12. Kamble, S.S.; Gacche, R.N. Evaluation of anti-breast cancer, anti-angiogenic and antioxidant properties of selected medicinal plants. Eur. J. Integr. Med. 2019, 25, 13-19. [CrossRef]

13. Hasan, N.; Mamun, A.; Belal, H.; Rahman, A.; Ali, H.; Tasnin, N.; Ara, T.; Rabbi, A.; Asaduzzaman, M.; Islam, A. A report on antioxidant and antibacterial properties of Callistemon viminalis leaf. Int. J. Pharm. Sci. Res. 2016, 1, 36-41.

14. Tiwari, U.; Jadon, M.; Nigam, D. Evaluation of antioxidant and antibacterial activities of methanolic leaf extract of Calistemon viminalis. Int. J. Pharm. Sci. Bus. Manag. 2014, 2, 1-12.

15. Bhagat, M.; Sangral, M.; Pandita, S.; Gupta, S.; Bindu, K. Pleiotropic chemodiversity in extracts and Essential oil of Melaleuca viminalis and Melaleuca armillaris of Myrtaceae Family. J. Explor. Res. Pharmacol. 2017, 2, 113-120. [CrossRef]

16. Abdelhady, M.I.; Youns, M. In-vitro evaluation of the antidiabetic activity of bottle brush plants. RRBS 2014, 9, 134-136. 
17. Shareef, H.; Naeem, S.; Zaheer, E. Comparative analgesic activity of selected medicinal plants from Pakistan. Proc. Pak. Acad. Sci. B Life Environ. Sci. 2019, 56, 57-67.

18. Mathy-Hartert, M.; Bourgeois, E.; Grulke, S.; Deby-Dupont, G.; Caudron, I.; Deby, C.; Lamy, M.; Serteyn, D. Purification of myeloperoxidase from equine polymorphonuclear leucocytes. Can. J. Vet. Res. 1998, 62, 127-132. [PubMed]

19. Vellosa, J.C.R.; Regasini, L.O.; Khalil, N.M.; Bolzani, V.d.S.; Khalil, O.A.; Manente, F.A.; Pasquini Netto, H.; Oliveira, O.M. Antioxidant and cytotoxic studies for kaempferol, quercetin and isoquercitrin. Eclética Quim. 2011, 36, 7-20. [CrossRef]

20. Ostuni, M.A.; Gelinotte, M.; Bizouarn, T.; Baciou, L.; Houée-Levin, C. Targeting NADPH-oxidase by reactive oxygen species reveals an initial sensitive step in the assembly process. Free Radic. Biol. Med. 2010, 49, 900-907. [CrossRef]

21. Cho, K.J.; Seo, J.M.; Kim, J.H. Bioactive lipoxygenase metabolites stimulation of NADPH oxidases and reactive oxygen species. Mol. Cells 2011, 32, 1-5. [CrossRef] [PubMed]

22. Ali, S.A.; Awad, S.M.; Said, A.M.; Mahgoub, S.; Taha, H.; Ahmed, N.M. Design, synthesis, molecular modelling and biological evaluation of novel 3-(2-naphthyl)-1-phenyl-1H-pyrazole derivatives as potent antioxidants and 15-Lipoxygenase inhibitors. J. Enzym. Inhib. Med. Chem. 2020, 35, 847-863. [CrossRef]

23. Yun, M.R.; Park, H.M.; Seo, K.W.; Lee, S.J.; Im, D.S.; Kim, C.D. 5-Lipoxygenase plays an essential role in 4-HNE-enhanced ROS production in murine macrophages via activation of NADPH oxidase. Free Radic. Res. 2010, 44, 742-750. [CrossRef]

24. Singh, A.; Kaur, M.; Sharma, S.; Bhatti, R.; Singh, P. Rational design, synthesis and evaluation of chromone-indole and chromonepyrazole based conjugates: Identification of a lead for anti-inflammatory drug. Eur. J. Med. Chem. 2014, 77, 185-192. [CrossRef]

25. Kumar, R.; Singh, A.K.; Kumar, M.; Shekhar, S.; Rai, N.; Kaur, P.; Parshad, R.; Dey, S. Serum 5-LOX: A progressive protein marker for breast cancer and new approach for therapeutic target. Carcinogenesis 2016, 37, 912-917. [CrossRef]

26. Grivennikov, S.I.; Greten, F.R.; Karin, M. Immunity, inflammation, and cancer. Cell 2010, 140, 883-899. [CrossRef] [PubMed]

27. Shalapour, S.; Karin, M. Immunity, inflammation, and cancer: An eternal fight between good and evil. J. Clin. Investig. 2015, 125, 3347-3355. [CrossRef]

28. Sun, Q.Y.; Zhou, H.H.; Mao, X.Y. Emerging Roles of 5-Lipoxygenase Phosphorylation in Inflammation and Cell Death. Oxid. Med. Cell. Longev. 2019, 2019, 2749173. [CrossRef] [PubMed]

29. Harris, R.E.; Beebe, J.; Schwartzbaum, J.J.W.A.o.S.J. Chemoprevention of breast cancer by cyclooxygenase and lipoxygenase inhibitors. World Acad. Sci. 2020, 2, 14-18. [CrossRef]

30. Xu, X.M.; Deng, J.J.; Yuan, G.J.; Yang, F.; Guo, H.T.; Xiang, M.; Ge, W.; Wu, Y.G. 5-Lipoxygenase contributes to the progression of hepatocellular carcinoma. Mol. Med. Rep. 2011, 4, 1195-1200. [CrossRef] [PubMed]

31. Zhou, G.X.; Ding, X.L.; Wu, S.B.; Zhang, H.F.; Cao, W.; Qu, L.S.; Zhang, H. Inhibition of 5-lipoxygenase triggers apoptosis in pancreatic cancer cells. Oncol. Rep. 2015, 33, 661-668. [CrossRef]

32. Steele, V.E.; Holmes, C.A.; Hawk, E.T.; Kopelovich, L.; Lubet, R.A.; Crowell, J.A.; Sigman, C.C.; Kelloff, G.J. Lipoxygenase inhibitors as potential cancer chemopreventives. Cancer Epidemiol. Biomark. Prev. 1999, 8, 467-483.

33. Nordberg, J.; Arner, E.S. Reactive oxygen species, antioxidants, and the mammalian thioredoxin system. Free Radic. Biol. Med. 2001, 31, 1287-1312. [CrossRef]

34. Ajila, C.M.; Prasada Rao, U.J. Protection against hydrogen peroxide induced oxidative damage in rat erythrocytes by Mangifera indica L. peel extract. Food Chem. Toxicol. 2008, 46, 303-309. [CrossRef] [PubMed]

35. Agrawal, P.K. Carbon-13 NMR of Flavonoids; Elsevier: Amsterdam, The Netherlands, 2013.

36. Harborne, J.B.; Mabry, T.J. The Flavonoids: Advances in Research; Springer: Berlin/Heidelberg, Germany, 1982.

37. Mabry, T.J.; Markham, K.; Thomas, M. The Determination and Interpretation of NMR Spectra of Flavonoids. In The Systematic Identification of Flavonoids; Springer: Berlin/Heidelberg, Germany, 1970; pp. 253-273.

38. Webby, R.F. A flavonol triglycoside from Actinidia arguta var. giraldii. Phytochemistry 1991, 30, 2443-2444. [CrossRef]

39. Iwashina, T.; Kamenosono, K.; Hatta, H. Flavonoid glycosides from leaves of Aucuba japonica and Helwingia japonica (Comaceae): Phytochemical relationship with the genus Cornus. J. Jpn. Bot. 1997, 72, 337-346.

40. Salman, H.; Ramasamy, S.; Mahmood, B. Detection of caffeic and chlorogenic acids from methanolic extract of Annona squamosa bark by LC-ESI-MS/MS. J. Intercult. Ethnopharmacol. 2018, 7, 76-81. [CrossRef]

41. BenSaad, L.A.; Kim, K.H.; Quah, C.C.; Kim, W.R.; Shahimi, M. Anti-inflammatory potential of ellagic acid, gallic acid and punicalagin A\&B isolated from Punica granatum. BMC Complement. Altern. Med. 2017, 17, 1-10. [CrossRef]

42. Barakat, H.H.; Hussein, S.A.; Marzouk, M.S.; Merfort, I.; Linscheid, M.; Nawwar, M.A. Polyphenolic metabolites of Epilobium hirsutum. Phytochemistry 1997, 46, 935-941. [CrossRef]

43. Nawwar, M.; Ayoub, N.; El-Raey, M.; Zaghloul, S.; Hashem, A.; Mostafa, E.; Eldahshan, O.; Lindequist, U.; Linscheid, M.W. Acylated flavonol diglucosides from Ammania auriculata. Z. Nat. C J. Biosci. 2015, 70, 39-43. [CrossRef]

44. Gjersing, E.; Happs, R.M.; Sykes, R.W.; Doeppke, C.; Davis, M.F. Rapid determination of sugar content in biomass hydrolysates using nuclear magnetic resonance spectroscopy. Biotechnol. Bioeng. 2013, 110, 721-728. [CrossRef] [PubMed]

45. Tabata, N.; Ohyama, Y.; Tomoda, H.; Abe, T.; Namikoshi, M.; Omura, S. Structure elucidation of roselipins, inhibitors of diacylglycerol acyltransferase produced by gliodadium roseum KF-1040. J. Antibiot. 1999, 52, 815-826. [CrossRef] [PubMed]

46. Gorin, P.A.; Mazurek, M. Further studies on the assignment of signals in 13C magnetic resonance spectra of aldoses and derived methyl glycosides. Can. J. Chem. 1975, 53, 1212-1223. [CrossRef]

47. Okuda, T.; Yoshida, T.; Ashida, M.; Yazaki, K. Tannis of Casuarina and Stachyurus species. Part 1. Structures of pendunculagin, casuarictin, strictinin, casuarinin, casuariin, and stachyurin. J. Chem. Soc. Perkin Trans. 1 1983, 1765-1772. [CrossRef] 
48. Moharram, F.; Marzouk, M.; El-Toumy, S.; Ahmed, A.; Aboutabl, E. Polyphenols of Melaleuca quinquenervia leavespharmacological studies of grandinin. Phytother. Res. 2003, 17, 767-773. [CrossRef]

49. Vivas, N.; Laguerre, M.; Glories, Y.; Bourgeois, G.; Vitry, C. Structure simulation of two ellagitannins from Quercus robur L. Phytochemistry 1995, 39, 1193-1199. [CrossRef]

50. Erkan, N.; Ayranci, G.; Ayranci, E. Antioxidant activities of rosemary (Rosmarinus Officinalis L.) extract, blackseed (Nigella sativa L.) Essential oil, carnosic acid, rosmarinic acid and sesamol. Food Chem. 2008, 110, 76-82. [CrossRef]

51. Moukette, B.M.; Pieme, C.A.; Njimou, J.R.; Biapa, C.P.N.; Marco, B.; Ngogang, J.Y. In vitro antioxidant properties, free radicals scavenging activities of extracts and polyphenol composition of a non-timber forest product used as spice: Monodora myristica. Biol. Res. 2015, 48, 1-17. [CrossRef]

52. Bhakta, D.; Siva, R. Amelioration of oxidative stress in bio-membranes and macromolecules by non-toxic dye from Morinda tinctoria (Roxb.) roots. Food Chem. Toxicol. 2012, 50, 2062-2069. [CrossRef]

53. Ialenti, A.; Moncada, S.; Di Rosa, M. Modulation of adjuvant arthritis by endogenous nitric oxide. Br. J. Pharm. 1993, 110, 701-706. [CrossRef] [PubMed]

54. Halliwell, B.; Gutteridge, J.M. Free Radicals in Biology and Medicine; Oxford University Press: Oxford, UK, 2015.

55. Mishra, A.; Sharma, A.K.; Kumar, S.; Saxena, A.K.; Pandey, A.K. Bauhinia variegata leaf extracts exhibit considerable antibacterial, antioxidant, and anticancer activities. Biomed. Res. Int. 2013, 2013, 915436. [CrossRef]

56. Brown, E.J.; Khodr, H.; Hider, C.R.; Rice-Evans, C.A. Structural dependence of flavonoid interactions with $\mathrm{Cu}^{2+}$ ions: Implications for their antioxidant properties. Biochem. J. 1998, 330, 1173-1178. [CrossRef] [PubMed]

57. Alfa, H.H.; Arroo, R.R.J. Over 3 decades of research on dietary flavonoid antioxidants and cancer prevention: What have we achieved? Phytochem. Rev. 2019, 18, 989-1004. [CrossRef]

58. Heim, K.E.; Tagliaferro, A.R.; Bobilya, D.J. Flavonoid antioxidants: Chemistry, metabolism and structure-activity relationships. J. Nutr. Biochem. 2002, 13, 572-584. [CrossRef]

59. Pandey, A.K.; Mishra, A.K.; Mishra, A. Antifungal and antioxidative potential of oil and extracts derived from leaves of Indian spice plant Cinnamomum tamala. Cell. Mol. Biol. 2012, 58, 142-147.

60. Cao, G.; Sofic, E.; Prior, R.L. Antioxidant and prooxidant behavior of flavonoids: Structure-activity relationships. Free Radic. Biol. Med. 1997, 22, 749-760. [CrossRef]

61. Ozgen, S.; Kilinc, O.K.; Selamoğlu, Z. Antioxidant activity of quercetin: A mechanistic review. Turk. J. Agric. Food Sci. Technol. 2016, 4, 1134-1138. [CrossRef]

62. Yen, G.-C.; Duh, P.-D.; Tsai, H.-L. Antioxidant and pro-oxidant properties of ascorbic acid and gallic acid. Food Chem. 2002, 79, 307-313. [CrossRef]

63. Boora, F.; Chirisa, E.; Mukanganyama, S. Evaluation of nitrite radical scavenging properties of selected Zimbabwean plant extracts and their phytoconstituents. J. Food Process. 2014, 2014, 1-7. [CrossRef]

64. Kaur, R.; Singh, B.; Arora, S. Amelioration of oxidative damage by methyl gallate in different in vitro models. Phytopharmacology 2011, 1, 82-94.

65. Hsu, F.L.; Huang, W.J.; Wu, T.H.; Lee, M.H.; Chen, L.C.; Lu, H.J.; Hou, W.C.; Lin, M.H. Evaluation of antioxidant and free radical scavenging capacities of polyphenolics from pods of Caesalpinia pulcherrima. Int. J. Mol. Sci. 2012, 13, 6073-6088. [CrossRef]

66. Afsar, T.; Razak, S.; Shabbir, M.; Khan, M.R. Antioxidant activity of polyphenolic compounds isolated from ethyl-acetate fraction of Acacia hydaspica R. Parker. Chem. Cent. J. 2018, 12, 5. [CrossRef]

67. Marzouk, M.S.; Moharram, F.A.; Mohamed, M.A.; Gamal-Eldeen, A.M.; Aboutabl, E.A. Anticancer and antioxidant tannins from Pimenta dioica leaves. Z. Nat. C J. Biosci. 2007, 62, 526-536. [CrossRef]

68. Gülçin, İ. Antioxidant activity of caffeic acid (3,4-dihydroxycinnamic acid). Toxicology 2006, 217, 213-220. [CrossRef]

69. Wu, L. Effect of chlorogenic acid on antioxidant activity of Flos lonicerae extracts. J. Zhejiang Univ. Sci. B 2007, 8, 673-679. [CrossRef]

70. Han, D.H.; Lee, M.J.; Kim, J.H. Antioxidant and apoptosis-inducing activities of ellagic acid. Anticancer Res. 2006, 26, 3601-3606.

71. Bray, F.; Ferlay, J.; Soerjomataram, I.; Siegel, R.L.; Torre, L.A.; Jemal, A. Global cancer statistics 2018: GLOBOCAN estimates of incidence and mortality worldwide for 36 cancers in 185 countries. Ca Cancer J. Clin. 2018, 68, 394-424. [CrossRef] [PubMed]

72. Examinati, R.R.I.N.; Wulandari, A.P.; Putri Huspa, D.H.; Andayaningsih, P. Cytotoxicity of aromatic compound from an endophytic fungus, Cladosporium sp. En-S01. Int. J. Curr. Pharm. Res. 2018, 10, 10-12. [CrossRef]

73. McGuire, S. World Cancer Report 2014; World Health Organization, International Agency for Research on Cancer, WHO Press: Geneva, Switzerland, 2015.

74. Batra, P.; Sharma, A.K. Anti-cancer potential of flavonoids: Recent trends and future perspectives. 3 Biotech 2013, 3, 439-459. [CrossRef] [PubMed]

75. Imran, M.; Salehi, B.; Sharifi-Rad, J.; Aslam Gondal, T.; Saeed, F.; Imran, A.; Shahbaz, M.; Tsouh Fokou, P.V.; Umair Arshad, M.; Khan, H.; et al. Kaempferol: A key emphasis to its anticancer potential. Molecules 2019, 24, 2277. [CrossRef] [PubMed]

76. Rauf, A.; Imran, M.; Khan, I.A.; Ur-Rehman, M.; Gilani, S.A.; Mehmood, Z.; Mubarak, M.S. Anticancer potential of quercetin: A comprehensive review. Phytother. Res. 2018, 32, 2109-2130. [CrossRef] [PubMed]

77. Senawong, T.; Khaopha, S.; Misuna, S.; Komaikul, J.; Senawong, G.; Wongphakham, P.; Yunchalard, S. Phenolic acid composition and anticancer activity against human cancer cell lines of the commercially available fermentation products of Houttuynia cordata. Sci. Asia 2014, 40, 420-427. [CrossRef] 
78. Gilbert, N.C.; Gerstmeier, J.; Schexnaydre, E.E.; Börner, F.; Garscha, U.; Neau, D.B.; Werz, O.; Newcomer, M.E. Structural and mechanistic insights into 5-lipoxygenase inhibition by natural products. Nat. Chem. Biol. 2020, 16, 783-790. [CrossRef] [PubMed]

79. Mohamed, R.; Tarannum, S.; Yariswamy, M.; Vivek, H.K.; Siddesha, J.M.; Angaswamy, N.; Vishwanath, B.S. Ascorbic acid 6-palmitate: A potent inhibitor of human and soybean lipoxygenase-dependent lipid peroxidation. J. Pharm. Pharm. 2014, 66, 769-778. [CrossRef]

80. Borbulevych, O.Y.; Jankun, J.; Selman, S.H.; Skrzypczak-Jankun, E. Lipoxygenase interactions with natural flavonoid, quercetin, reveal a complex with protocatechuic acid in its X-ray structure at $2.1 \AA$ resolution. Proteins Struct. Funct. Bioinform. 2004, 54, 13-19. [CrossRef]

81. Trott, O.; Olson, A.J. AutoDock Vina: Improving the speed and accuracy of docking with a new scoring function, efficient optimization, and multithreading. J. Comput. Chem. 2010, 31, 455-461. [CrossRef] [PubMed]

82. Hiermann, A. Die Untersuchung potentieller Wirkstoffe in Epilobium-Arten. 1. Mitteilung: Aufklärung der Flavonoidmuster. Sci. Pharm. 1983, 51, 158-167.

83. Gupta, R.K.; Al-Shafi, S.M.K.; Layden, K.; Haslam, E. The metabolism of gallic acid and hexahydroxydiphenic acid in plants. Part 2. Esters of (S)-hexahydroxydiphenic acid with D-glucopyranose (4 C 1). J. Chem. Soc. Perkin Trans. 1 1982, 2525-2534. [CrossRef]

84. Stahl, E.; Dumont, E. Gradient thin-layer chromatography on defined "Acidic-Basic" slica gel layers. J. Chromatogr. Sci. 1969, 7, 517-525. [CrossRef]

85. Nahar, L.; Russell, W.R.; Middleton, M.; Shoeb, M.; Sarker, S.D. Antioxidant phenylacetic acid derivatives from the seeds of Ilex aquifolium. Acta Pharm. 2005, 55, 187-193.

86. Ebrahimzadeh, M.A.; Pourmorad, F.; Hafezi, S. Antioxidant activities of Iranian corn silk. Turk. J. Biol. 2008, 32, 43-49.

87. Li, X. Improved pyrogallol autoxidation method: A reliable and cheap superoxide-scavenging assay suitable for all antioxidants. J. Agric. Food Chem. 2012, 60, 6418-6424. [CrossRef] [PubMed]

88. Mosmann, T. Rapid colorimetric assay for cellular growth and survival: Application to proliferation and cytotoxicity assays. J. Immunol. Methods 1983, 65, 55-63. [CrossRef] 